\title{
The life, publications and new taxa of Qabir Argaman (Carol Nagy)
}

\author{
Lynn S. Kimsey', Denis J. Brothers² \\ I Department of Entomology \& Nematology, University of California, Davis, CA 95616, USA 2 School of Life \\ Sciences, University of KwaZulu-Natal (Pietermaritzburg), Private Bag X01, Scottsville, 3209 South Africa \\ Corresponding author: Lynn S. Kimsey (lskimsey@ucdavis.edu)
}

Academic editor: Michael Obl | Received 30 January 2016 | Accepted 8 May 2016 | Published 27 June 2016

http://zoobank.org/FD22EC27-0365-467E-B699-34D6CD0F9B8B

Citation: Kimsey LS, Brothers DJ (2016) The life, publications and new taxa of Qabir Argaman (Carol Nagy). Journal of Hymenoptera Research 50: 141-178. doi: 10.3897/JHR.50.7973

\begin{abstract}
This biography of the Hungarian/Romanian/Israeli hymenopterist Qabir Argaman (= Carol Nagy) provides a list of his publications (except for newspaper articles) and the new taxa and new replacement names he proposed. Dr. Argaman began his career in Hungary, publishing under the name Carol Nagy. He later moved to Romania and finally moved to Israel, where he assumed the name Qabir Argaman. In total, he published 84 articles on the order Hymenoptera and described 348 new taxa (2 families, 11 subfamilies, 58 tribes, 153 genera or subgenera, and 125 species or subspecies) in 15 families, as well as 1 new species of Scarabaeidae (Coleoptera).
\end{abstract}

\section{Keywords}

Carol Grosman, Károly Nagy, Hymenoptera, Scarabaeidae

\section{Introduction}

The majority of insect taxonomists tend to focus on a single family group for the majority of their careers. However, others have more diverse interests. The taxonomist Qabir Argaman (Fig. 1) worked on a wide diversity of Hymenoptera families during his career between 1965 and 2003, and he did so under different names. Early on he published under the names Carol Nagy or Károly Nagy and later under the name 


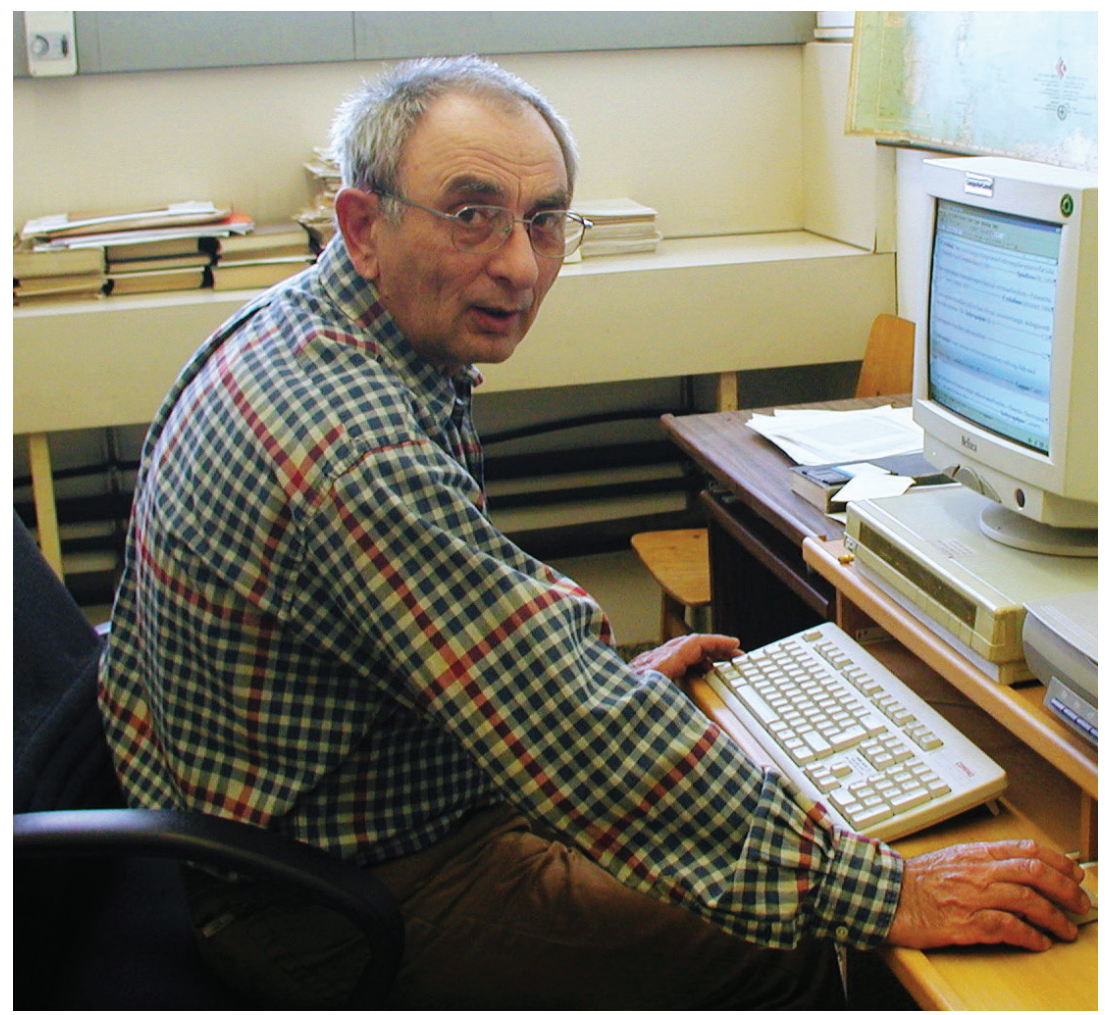

Figure I. Qabir Argaman at work in Israel (photo courtesy of the Israeli Ministry of Agriculture).

Qabir Argaman. In total he published new taxa in 15 hymenopteran families, Ampulicidae, Bethylidae, Braconidae, Bradynobaenidae (as Apterogynidae), Dryinidae, Heterogynaidae, Kislevidae, Mutillidae, Perilampidae, Plumariidae, Sclerogibbidae, Scolebythidae, Scoliidae, Sierolomorphidae and Tiphiidae (mostly as Myzinidae), as well as one new species of Scarabaeidae (Coleoptera). Because of his changes of surname, the obscure nature of some of the journals he published in and the diversity of families involved, it is difficult to find many of his publications. We have attempted to do so here, and also give a brief account of his life based on many (sometimes conflicting) sources.

Károly (Karol/Carol) György (George) Nagy was born on January 15, 1940 in Oradea, Romania (the region was transferred to Hungary later that year, but restored to Romania after the war). In the early 1960's he attended university in Romania where he developed an interest in wasp taxonomy. In 1965 he began publishing on the Mutillidae, Bethylidae and "heterogyne Hymenoptera" of Romania. He graduated in 1967 from Babeş-Bolyai University, in Cluj-Napoca, Romania with an MSc degree in biology. He then studied under László Móczár at the University of Szeged in Hungary, where he received his $\mathrm{PhD}$ in 1968. Thereafter he held a position at the Marine Research Institute, in Agigea-Constantza, Romania, where he studied the taxonomy, biology and zoogeography of the Romanian wasp fauna. He obtained his DSc in 1974 
from the University "Al. I. Cuza” in Iaşi, his thesis on the scolioids of Romania being supervised by Mihai Constantineanu.

In 1980 Carol Nagy moved from Agigea, Romania to Israel (Menke 1980). According to a note in Sphecos (Menke 1981) he and his family left Romania with only $40 \mathrm{~kg}$ of baggage, which consisted mostly of clothes for their baby. He had to leave behind his entomological library and collections in Romania, lived for a time in a camp for immigrants, and started a new life in a new country with all the attendant challenges - learning a new language, trying to find employment (difficult for a wasp taxonomist in such a small country and without his literature resources), and trying to find a permanent home. During this period he briefly changed his surname from Nagy to Grosman, but was required by Israeli immigration regulations to adopt a Hebrew name (Menke 1982). He then became Qabir Argaman (ריבכ ןמגרא), and from the mid 1980's his papers were all published under this name. In 1981 he began working as an insect taxonomist for the Israeli Ministry of Agriculture, Plant Protection Department, in Bet Dagan, working on insects of agricultural importance. However, he also continued his work on a diversity of wasp families, but suffered from shortages of basic supplies such as pins and boxes, an initial lack of a collection and constraints on field work (the threat of terrorism being a concern) (Menke 1987). He worked for the Ministry of Agriculture until his death in October 2003 at the age of 63.

Nagy's research interests changed over the years. Between 1965 and 1968 his studies focused primarily on the Romanian fauna. In 1968 he described a new species of Mutillidae from Sudan (Nagy1968b) and this began the expansion of his research interests into other parts of the world. In the 1970's he began working on the European bethylid and mutillid faunas and small collections of ampulicids from Africa, tiphiids, scolebythids, South American Plumariiidae and Mongolian scoliids. There is a gap in his publications between 1980 and 1986, which is the period when he moved his family to Israel. In the remainder of the 1990's he began new studies of Perilampidae, Sierolomorphidae and Scoliidae and continued his work on the Bethylidae, Sclerogibbidae and Tiphiidae. He produced several papers dealing with the higherlevel classification of various groups, describing many new genera and other higher taxa supposedly based on phylogenetic principles requiring naming of monophyletic groups, but never provided any cladistic or other analyses justifying his decisions. His publications were primarily limited to descriptions of new taxa and faunal lists. $\mathrm{He}$ never produced any taxonomic revisions. Subsequent workers have generally rejected his excessively split approach and synonymized most of his names, or else deliberately ignored them (e.g. Osten 2005). His idiosyncratic approach and involvement with such a diversity of groups means that any workers having to deal with his taxa and names should be aware of these complexities to be able to evaluate them properly.

According to an unpublished obituary provided by the Israeli Ministry of Agriculture, Argaman's personal collection, primarily accumulated once he arrived in Israel, also included some materials dating from his early work in Hungary and Romania. According to Laibale Friedman (in Romano 2012), after Argaman's death the collection was broken up, part being sold privately, and the remainder being 
donated by his family to the Israeli Ministry of Agriculture and transferred to the Tel Aviv University Collection. For unknown reasons, Argaman apparently removed labels from some specimens, including types, leaving them without any labels at all, and making the identification of such type specimens essentially impossible. (When DJB briefly visited him in Tel Aviv in 1985, he gained the impression that Argaman was suspicious of the motives of others and jealously guarded his specimens, not being willing to let them out of his sight; this attitude probably resulted from the personal difficulties he had endured, and may explain the removal of labels.) Repositories of his types, according to his publications and information provided by collection managers, include the following:

Argaman Coll. - much of his personal collection now resides in Tel Aviv (see below), the location(s) and extent of the remainder are unknown.

Bar Ilan - Department of Life Sciences, Bar Ilan University, Ramat Gan, Israel.

Berlin - Museum für Naturkunde, Berlin, Germany.

Brussels - Royal Belgian Institute of Natural Sciences, Brussels, Belgium.

Budapest - Magyar Természettudományi Múzeum, Budapest, Hungary.

Cluj - Zoological Museum, Universitatea Babeș-Bolyai, Cluj-Napoca, Romania.

Copenhagen - Statens Naturhistoriske Museum, Copenhagen, Denmark.

Fruhstorfer Coll. - Museum für Naturkunde, Berlin, Germany.

Geneva - Muséum d'histoire naturelle de la Ville, Geneva, Switzerland.

Genoa - Museo Civico di Storia Naturale "Giacomo Doria", Genoa, Italy.

Hamburg - Zoologisches Museum, Hamburg, Germany.

Nagy Coll. - a small part of this collection resides in Tel Aviv (see below), the location of the rest is unknown.

Nonveiller Coll. - the private collection of the late Guido Nonveiller, Zemun, Serbia, now housed in Biologiezentrum, Oberösterreichs Landesmuseum, Linz, Austria.

Pagliano Coll. - the private collection of Guido Pagliano, Turin, Italy

Paris - Muséum National d'Histoire Naturelle, Paris, France

Senckenberg - Senckenberg Deutsches Entomologisches Institut, Berlin, Germany.

Tel Aviv - The Steinhardt Museum of Natural History and National Research Center,

Tel Aviv University, Tel Aviv, Israel.

Washington - U. S. National Museum of Natural History, Washington, D. C., USA.

Lists of his theses and publications are given below (compiled from various sources, importantly using information provided by Laibale Friedman which unfortunately had all titles translated into English). A complete tabulation of new taxa described by him is given in Table 1, followed by an Appendix comprising a detailed list of his new taxa and new names, including type locality and repository for each species. If the repository has been confirmed by the date of this publication it is indicated as such. Others are yet to be confirmed. This is another problem to be resolved; it has not been possible to determine the location of most of the aculeate wasp types described by him. Some, particularly the aculeates, may still be in Romania. 
Table I. Summary of new taxa described by Nagy/Argaman; new families are indicated by asterisks $(*)$, new replacement names are given between parentheses ( ), and unavailable names between square brackets [ ].

\begin{tabular}{|c|c|c|c|c|c|c|c|c|c|c|}
\hline \multirow{2}{*}{ Order } & \multirow{2}{*}{ Family } & \multirow{2}{*}{ Subfam. } & \multirow{2}{*}{ Tribe } & \multirow{2}{*}{$\begin{array}{l}\text { Genus/ } \\
\text { Subgen. }\end{array}$} & \multirow{2}{*}{$\begin{array}{l}\text { Species/ } \\
\text { Subsp. }\end{array}$} & \multicolumn{5}{|c|}{ Geographic Region of New Species } \\
\hline & & & & & & Europe & Asia & Africa & Americas & Australia \\
\hline Coleoptera & Scarabaeidae & & & & 1 & & 1 & & & \\
\hline \multirow{15}{*}{ Hymenoptera } & Ampulicidae & & & & 5 & & 5 & & & \\
\hline & Bradynobaenidae & & 4 & 7 & 1 & & & 1 & & \\
\hline & Bethylidae & 3 & 3 & 12 & 29 & 10 & 11 & 8 & & \\
\hline & Braconidae & & & 1 & & & & & & \\
\hline & Dryinidae & & & & 2 & 1 & 1 & & & \\
\hline & Heterogynaidae* & & & 2 & 2 & 1 & 1 & & & \\
\hline & Kislevidae* & & & 1 & 1 & & 1 & & & \\
\hline & Mutillidae & 1 & 2 & 3 & 30 & 8 & 5 & 1 & 16 & \\
\hline & Perilampidae & & & 26 & $26(+3)$ & & 5 & 12 & 9 & \\
\hline & Plumariidae & & & & 5 & & & & 5 & \\
\hline & Sclerogibbidae & 2 & 2 & 1 & 2 & 1 & & 1 & & \\
\hline & Scolebythidae & & & 1 & 1 & & & 1 & & 1 \\
\hline & Scoliidae & 1 & 22 & $61(+3)$ & $3[+3]$ & 1 & 2 & & & \\
\hline & Sierolomorphidae & & & & 2 & & 2 & & & \\
\hline & Tiphiidae & 4 & 25 & 38 & 15 & 7 & 4 & 4 & & \\
\hline Totals & 2 & 11 & 58 & $153(+3)$ & $\begin{array}{c}125(+3) \\
{[+3]}\end{array}$ & 29 & 38 & 28 & 30 & 1 \\
\hline
\end{tabular}

Unpublished theses by Carol Nagy (The information on these appears in the list from Friedman; we have not been able to locate them to confirm the details or original titles, however, so several peculiarities are evident.)

Nagy CG (1967) [Contributions to the knowledge of the heterogynoid Hymenoptera from the fauna of Romania.] Master of Science Thesis, University "Babeş-Bolyai" in Cluj, 1-87. [Romanian]

Nagy CG (1968) [The Hymenoptera Proctotrupoidea in the fauna of Romania.] Doctor of Philosophy Thesis, Constantza-Szeged-Budapest. 1-70. [Romanian]

Nagy CG (1974) [Contributions to the study of Scolioidea (Hymenoptera) from the fauna of Romania, from systematical, biological, ecological and economical viewpoints.] Doctor of Science Thesis, Universitatea "Alexandru Ioan Cuza" din Iaşi, 1-300, 302 figs. [Romanian]

\section{Publications by Carol Nagy/Qabir Argaman}

This list includes all publications in books, journals or magazines for which page numbers are available, but it excludes his many (at least 117, from 1967 to 1978) "popular" contributions to newspapers or small local periodicals on a very wide range of subjects (butterflies, snakes, honey bees, birds, scientific expeditions, biological control, ants in 
forests, scientific methods, oceanology, sea snakes, Antarctic exploration, obituaries, physics of the universe, linguistics, conference reports, turtle conservation, human development, psychoanalysis, archeology, environmental conservation, pogonophorans, black widow spiders, human facial expressions, yogis in ancient India, marine rescues, fossil corals, hare behavior, vitamins, human social behavior, animal suicides, Drosophila cultures, beach events, forest mammals, Oriental archeology, energy sources, noise pollution, ecological non-equilibria, species concepts, concept of life, scientific literature, sea gulls, sand-nesting wasps and bees, general theory of relativity, wildlife conservation, crows, biospeleology and meiobenthal faunas, autobiography, guppies, pollution, medusas, blue-green algae, shipwrecks, lunar orbits, coffee cultivation, scientific ethics, biological systems, animal intelligence, calendars, lagoons, importance of stinging wasps, pheromones, bee pollination ecology, hedgehogs, biology of cancer, dolphins, cybernetics of life, ocean plankton, hypochondria, human genetics, and dogs). The more cultural publications included below were generally authored by "Nagy G Károly", reflected here as "Nagy KG". Where easily available, actual dates of publication are provided, and the sequence attempts to reflect the temporal sequence of publication (primarily based on the sequence in the list mentioned above). Unfortunately, we have been unable to obtain copies of all of the entries and have therefore not been able to provide the original titles for those non-English papers we have not seen, but indicate the original language. His papers were in Romanian, German, Hungarian, French, English and Hebrew; English translations of Hungarian and Romanian titles are given in addition to the originals since these are less familiar languages to most, but only English translations of the Hebrew titles are given. Articles we have not been able to locate are indicated by an asterisk $(*)$.

Nagy CGh (1965) Scolioide noi pentru fauna R.P.R. [Scolioids new to the fauna of Romania]. Studia Universitatis Babeş-Bolyai (Series Biologia) 1: 57-59.

Nagy CGh (1966a, March 16) Ein neues Mutilliden-Subgenus aus Rumänien (Hymenoptera). Reichenbachia 6(13): 113-117.

Nagy CGh (1966b) Neue Bethyliden-Arten für die Fauna Rumäniens (Hymenoptera). Travaux du Muséum National d'Histoire Naturelle "Grigore Antipa" 6: 165-169.

Nagy CGh (1966c) Contribuţii la cunoaşterea himenopterelor heterogine din rezervaţiile naturale ale Dobrogii [Contributions to the knowledge of heterogyne Hymenoptera of nature reserves of Dobruja]. Ocrotirea Naturii 10(2): 223-228.

Nagy CGh, Stamp HM (1966) Katalog der Heterogyniden (Hymenoptera) aus der Sammlung Brukenthalmuseums in Sibiu. Rovartani Közlemények Folia Entomologica Hungarica (Series Nova) 19(27): 491-500.

Nagy CGh (1967a) Gonatopodine noi pentru fauna României (Hymenoptera: Dryinidae) [Gonatopodines new to the fauna of Romania]. Studia Universitatis Babeş-Bolyai (Series Biologica) 1: 123-125.

Nagy CGh (1967b, April 20) Une nouvelle espèce du genre Myrmilla Wesm. de la faune de la Roumanie (Hymenoptera, Mutillidae). Bollettino della Società Entomologica Italiana 97(3-4): 50-54. 
Nagy CGh (1967c, June 21) Systematisches Studium der Tiphiiden Rumäniens. Reichenbachia 8(24): 175-204.

Nagy CGh (1967d, June 21) Beiträge zur Kenntnis der rumänischen Scoliiden-Arten (Hymenoptera, Scoliidae). Reichenbachia 8(28): 221-226.

Nagy CGh (1967e) Contribution à l'étude de la Fam. Dryinidae (Hym.) dans la faune de la Roumanie. Travaux du Muséum National d'Histoire Naturelle "Grigore Antipa" 7: 331-337.

Nagy C (1967f) Himenopterele betilide - distrugători naturali al dăunătorilor din muzee [Hymenopteran bethylids - natural destroyers of pests in museums]. Revista Muzeelor 4(4): 321-322.

Nagy CGh (1967g) Description du mâle de Myrmilla subcornuta Mor. (Hym. Mutillidae). Deutsche Entomologische Zeitschrift (Neue Folge) 14(5): 473-476.

Nagy CGh (1967h) Contributions à la connaissance des hyménoptères Bethylidae de la faune roumaine. Rovartani Közlemények Folia Entomologica Hungarica (Series Nova) 20(8): 87-94.

Nagy CGh (1968a, March) Les femelles de Laelius anthrenivorus Trani (Hym. Bethylidae) attaquent l'homme. Rivista di Parassitologia 29(1): 71-74.

Nagy CG (1968b) Une nouvelle espèce du genre Dolichomutilla Ashm. (Hym., Mutillidae). Rovartani Közlemények Folia Entomologica Hungarica (Series Nova) 21(10): 147-151.

Nagy CGh (1968c, June 20) Quelques espèces nouvelles de Myrmillines dans la faune de la Roumanie (Hymenoptera, Mutillidae). Bollettino della Società Entomologica Italiana 98(3-6): 65-69.

Nagy CG (1968d) Observations écologiques sur l'espèce Smicromyrme septentrionalis Hffr. (Hym., Mutillidae). Acta Entomologica Bohemoslovaca 65: 375-378.

Nagy CG (1968e) The species of the family Methocidae [sic] in the Carpathian Basin. Opuscula Zoologica Budapest 8(1): 81-85.

Nagy KG (1968f, December) [The indefinite character of the notion of the species.] Korunk 27(12): 1859-1860. (Hungarian)*

Nagy CG (1968g) La présence du genre Holepyris Kieff. (Hym. Bethylidae) dans la faune de la Roumanie. Analele Ştiinţifice Universităţii “Al. I. Cuza” din Iaşi (Serie Nouă) Secţiunea II (Ştiinţe naturale) a) Biologie 14(2): 409-410, fig. 1.

Nagy C (1968h) Quelques espèces nouvelles d'Hyménoptères hétérogynes en Roumanie. Travaux du Muséum National d'Histoire Naturelle "Grigore Antipa” 8(2): 1029-1035.

Nagy CG (1968i) A new record of Mesitinae [sic] (Hymenoptera, Bethylidae). Memorie della Società Entomologica Italiana 47: 168-176.

Nagy CG (1968j) [New contributions to the knowledge of the Hymenoptera Heterogynoidea from the fauna of Romania.] Comunicări Zoologice ale Societăţii de Ştiinţe Biologice 2: 115-120. (Romanian?)*

Nagy CGh (1969a [“1968”]) Les espèces du genre Smicromyrme Thoms. (Hym., Mutillidae) des dunes sablonneuses d'Agigea. Lucrările Sessiuni Ştiinţifice a Staţiunii de Cercetări Marine "Prof. loan Borcea" Agigea (1-2 noiembrie 1966) Volum Festiv, 219-224.

Nagy CG (1969b) A new taxon of the family Heterogynidae Latreille (Hym., Aculeata). Entomologische Mittielungen aus dem Zoologischen Staatsinstitut und Zoologischen Museum Hamburg 64: 299-303. 
Nagy CG (1969c) Capcană automată pentru insecte zburătoare [Automatic trap for flying insects]. Revista Muzeelor 6(2): 149-151.

Nagy CG (1969d) The female sex of Mesa petiolaris Mor. (Hymenoptera, Myzinidae). Opuscula Zoologica Budapest 9(2): 373-374.

Nagy CG (1969e) (Noona Dan Papers No. 90.) A new Philippine species and taxonomic notes on Bocchus Ashmead (Hym., Dryinidae). Entomologiske Meddelelser 37: 321-326.

Nagy CG (1969f) Evoluția rezervațiilor naturale Dobrogene [Evolution of the nature reserves in Dobruja]. Ocrotirea Naturii 13(2): 201-205.

Nagy CG (1969g, November 12) Considerations on the characters of living organisms. Acta Biologica Academiae Scientiarum Hungaricae 20(4): 351-357.

Nagy CG (1969h, December 12) The taxon of the genus Pseudotiphia Ashm. (Hymenoptera, Tiphiidae). Reichenbachia 12(13): 141-142.

Nagy CG (1969i) Sur la sous-famille Mesitinae [sic] Berland (Hym., Bethylidae). Lucrările Staţiunii de Cercetări Marine "Prof. Ioan Borcea" Agigea 3: 275-300, 19 pl.

Nagy CG (1970a) Apariția vieții sociale la Himenoptere [Emergence of social life in the Hymenoptera]. Natura 22(1): 78-79.

Nagy KG (1970b, January) [Conservation of the nature - the central problem of our age.] Korunk 29(1): 65-66. (Hungarian)*

Nagy CG (1970c) Further records on Mesitinae [sic] (Hymenoptera: Bethylidae). Acta Zoologica Academiae Scientiarum Hungaricae 16(1-2): 205-208

Nagy CG (1970d, March 31) The identity of the genera Bruesia Kieffer and Dermasothes Menozi.

Revue de Zoologie et de Botanique Africaines, Tervuren 81(1-2): 188-192.

Nagy CG (1970e, May 15) Über die in Europa vorkommenden mikropterischen BethylidenArten (Hym., Bethylidae). Nachrichtenblatt der Bayerischen Entomologen 18(4-6): 61-64.

Nagy CG (1970f, June 25) Further investigations on the heterogynoid wasps. Entomologische Mitteilungen aus dem Zoologischen Museum Hamburg 4(69): 83-86.

Nagy CG (1970g, June 25) Note on the Ephuta Say of America south of Mexico (Hymenoptera: Mutillidae). Entomologische Mitteilungen aus dem Zoologischen Museum Hamburg 4(69): 87-96.

Nagy CG (1970h) [Comments on the taxonomy and nomenclature of the commonest European species of turtles (Testudinata).] Búvár 15 [“25”]: 204. [Hungarian]*

Nagy KG (1970i) Dobrudzsa védett területeinek fejlődési irányvonala [Trend of development of Dobrudja's nature reserves]. Állattani Közlemények 57: 89-92. doi: 10.1002/ mmnz.19700460204

Nagy CG (1970j) Contribution toward a revision of the European species of the genus Epyris

Westw. (Hym., Bethylidae). Mitteilungen aus dem Museum für Naturkunde in Berlin 46(2): 265-272.

Nagy CG (1970k) Ergebnisse der zoologischen Forschungen von Dr. Z. Kaszab in der Mongolei. 221. Scoliiidae [sic] (Hymenoptera) (Results of the zoological expeditions of Dr. Z. Kaszab in Mongolia). Annales Historico-Naturales Musei Nationalis Hungarici Pars Zoologica 62: 321-324.

Nagy CG (1971a) A new Smicromyrme species from Iran (Hym., Mutillidae). Entomologische Mitteilungen aus dem Zoologischen Museum Hamburg 4(72): 167-169. 
Nagy GC (1971b, April 1) First record of the Old World species of Sierolomorpha Ashm. (Hym., Heterogynoidea). Reichenbachia 13(27): 247-249.

Nagy CG (1971c, July 25) Studies on the Ampulicidae (Hymenoptera). Bollettino della Società Entomologica Italiana 103(5-6): 103-107.

Nagy CG (1971d) Beobachtungen über die Rolle der Insekten des Supralitorals im rumänischen Küstenbereich des Schwarzen Meeres. Cercetări Marine IRCM Constanţa 2: 27-36.

Móczár L, Nagy C, Okáli I, Osychniuk AZ \& Szöllősi Gy (1972, January 31) Kárpát-medence Hymenoptera faunakatalógusainak (I-XXIV.) lelőhely jegyzéke (Cat. Hym. XXV.) [Directory of localities for the Catalogue of the Hymenopteran fauna (I-XXIV) of the Carpathian basin (Cat. Hym. XXV.)]. Folia Entomologica Hungarica Rovartani Közlemények (Series Nova) 25(7): 111-164.

Nagy CG (1972a, February 20) Taxonomic remarks on Mesitinae [sic] (Hymenoptera, Bethylidae). Memorie della Società Entomologica Italiana 51: 5-18.

Nagy CG (1972b) Records on the genus Smicromyrme Thoms, from Greece (Hym., Mutillidae). Biologia Gallo-Hellenica 4(1): 27-31.

Nagy CG (1972c) Two new species of Mutillidae (Hymenoptera) from Asia Minor and description of female Mutilla erronea. Bulletin of the Iraq Natural History Museum 5(2): 4-9.

Nagy CG (1972d) Ord. Hymenoptera - Superfam. Heterogynoidea (l'Entomofaune du "Grind" de Caraorman, Delta du Danube). Travaux du Muséum National d'Histoire Naturelle "Grigore Antipa" 12: 159-165.

Nagy CG (1972e) [Contributions to the knowledge of compositions, population dynamics and importance of the littoral fauna of Insects of the Romanian Black Sea coast.] Consfatuire Stiintifica Constantza, 111-112. [Romanian?] ]

Nagy CG (1972f) Contributions à l'étude des insectes du supralittoral du secteur roumain de la Mer Noire. Cercetări Marine IRCM Constanţa 3: 171-189.

Nagy CGh (1973a) Contribuţii la cunoaşterea himenopterelor heterogine din regiunea Crişana [Contributions to the knowledge of heterogyne Hymenoptera from the district of Crisana]. Nymphaea 1: 31-34.

Nagy KG (1973b, August) A hazai tatárok életéről [The domestic life of Tatars]. Korunk 32(8): 1241-1244.

Nagy CG (1973c, October 31) Revisionary studies on the family Plumariidae Bischoff (Hymenoptera, Heterogynoidea). Folia Entomologica Hungarica Rovartani Közlemények (Series Nova) 26(Suppl.): 255-267.

Nagy CG (1973d) La photoperiodicitée de Fucellia maritima Hal. Diptera, Muscidae. Cercetări Marine IRCM Constanţa 5-6: 355-357.

Nagy CG (1974a) [Contributions to the study of Scolioidea (Hymenoptera) from the fauna of Romania, from systematical, biological, ecological and economical viewpoints.] Summary of Doctor of Science Thesis, Universitatea "Alexandru Ioan Cuza” din Iaşi, The Publishing Center of the University, 1-23, 12 figs. [Romanian]*

Nagy CG (1974b, June 30) Bemerkungen zu der Szelenyi’schen Anschauung bezüglich Zoozönologie. Folia Entomologica Hungarica Rovartani Közlemények (Series Nova) 27(1): 145-153. 
Nagy CG (1974c, July 20) A new bethylid subfamily allied to Protopristocerinae (Hymenoptera Bethylidae). Bollettino della Società Entomologica Italiana 106(5-7): 126-129.

Nagy CG (1974d, December 31) A new genus and species of Tiphiidae (Hymenoptera) from Ethiopia. Folia Entomologica Hungarica Rovartani Közlemények (Series Nova) 27(2): 103-107.

Nagy CG (1975a) Taxonomical studies on species of the genus Icronatha Nagy (Hymenoptera, Tiphiidae). (With reference to two species new for the Greek fauna). Biologia GalloHellenica 6(1): 9-19.

Nagy CG (1975b) [Hymenoptera: Heterogynoidea, In: Monographic study of the fauna of "Iron Gate's" area.] Edited by the Romanian Academy of Sciences, Bucharest, 181-187. [Romanian]*

Nagy CG (1975c, March) A new genus of Scolebythidae (Hymenoptera) from South Africa and Australia. Journal of the Entomological Society of Southern Africa 38(1): 75-78.

Nagy CG (1975d) La reproduction du rotifere Hexarthra fennica pendant une période de pullulation de Xanthomonas lacustris. Rapports du Congrès de la Commission Internationale pour l'Exploration Scientifique de la Mer Méditerranée 23(3): 95-96.

Nagy CG (1975e) [Natural enemies of the giant garden snail Helix pomatia L. in orchards of Dobruja.] Lucrările Statiunii “Stejarul”, Ecologie Terestră şi Genetică 1974-1975: 25-26. (Romanian)*

Nagy CG (1976a) Redescription of Epyris evanescens Kieffer with notes on other Epyris Westw. species from Yugoslavia (Hymenoptera, Bethylidae). Acta Entomologica Jugoslavica 12(1-2): $5-10$.

Nagy CG (1976b, December) Bethylidae (Hymenoptera) parasitizing orchard caterpillars. Revue Roumaine de Biologie (Série de Biologie Animale) 21(2): 103-108.

Nagy CG (1976c) [The life-giving water surface. A study of the Black Sea's Hyponeuston.] Búvár 16 [“6”]: 254-259. [Hungarian]*

Nagy CG (1977a) [An exposure about my way, beliefs, dreams and possibilities toward science during the years at the college.] Diakszo 11: 57-59. [Hungarian]*

Nagy CG (1977b) Observations sur la faune relicte, sarmato-pontique de la lagune Sinoë. Rapports du Congrès de la Commission Internationale pour l'Exploration Scientifique de la Mer Méditerranée 24(6): 83-84.

Nagy KG (1977c) A vírus és a rák [The virus and cancer]. Antenna: Dacia Könyvkiadó, Kolozsvár-Napoca, 128 pp.*

Nagy CG (1977d) Notatka o ślimakach z laguny Sinoe Note on the snails from the Sinoe Lagoon. Acta Hydrobiologica 19(1): 89-92.

Nagy CG (1977e) Studii asupra muştelor acaliptrate din Delta Dunării [Studies on acalyptrate flies in the Danube Delta] (Diptera, Muscidae Aclyptratae [sic]). Peuce 5(Zoologie): 33-36.

Nagy CG (1977f) Contribuţii la cunoaşterea himenopterelor heterogine din Delta Dunării [Contributions to the knowledge of heterogyne Hymenoptera of the Danube Delta] (Hymenoptera, Heterogynoidea). Peuce 5(Zoologie): 53-54.

Nagy CG (1977g) Aspecte privind biologia dăunătorilor stufului şi paraziţilor lor în Delta Dunării [Aspects of the biology of pests of the common reed and their parasites in the Danube Delta]. Peuce 5(Zoologie): 105-108. 
Nagy CG (1978a) [Study on the existing discrepancy between cultural niveau of the mass media and the universal patrimony of the human knowledge.] Revista Mueveloedes 10: 1-2. (Hungarian)*

Nagy CG (1978b) A fekete-tengeri árapály övezet rovarcönológiája [The Black Sea tidal zone insect coenology]. Folia Entomologica Hungarica Rovartani Közlemények (Series Nova) 31(2): 299-303.

Nagy CG (1978c) [The species concept in parasitic Hymenoptera within the context of modern taxonomy.] In: Codreanu R (Ed.) Probleme de Biologie Evoluţionistă: Taxonomie şi Speciaţie. Ed. Académie Române, Bucharest, 117-122. [Romanian]*

Nagy KG (1979a, April) Környezetvédelem és marxi humanizmus [Environmental conservation and Marxist humanism]. Korunk 38(4): 250-254.

Nagy CG (1979b) Cartographie floristique dans la lagune Sinoë. Rapports du Congrès de la Commission International pour l'Exploration Scientifique de la Mer Méditerranée 25/26(3): 179-180.

Nagy CG (1980a) Rezervatia dunelor nisipoase de la Agigea. In: Pontus Euxinus: Studii şi Cercetări [The sandy dune reserve of Agigea. In: Black Sea: studies and research]. Complexul Muzeal de Ştiinţe ale Naturii, Constanţa, Vol. 1, 273-293.*

Nagy CG (1980b) Comparative zoobenthos investigations in the Histria and Nuntasi lakes during the period 1971-1976. Cercetări Marine IRCM Constanţa 12: 175-181.*

Argaman Q (1986a, February [“1985”]) Taxonomy of Heterogynaidae (Hymenoptera: Aculeata). Israel Journal of Entomology 19: 7-12.

Argaman Q (1986b) [A new Maladera in Israel (Coleoptera: Scarabaeidae)]. Shappirit 4: 41-46 (Hebrew), 67-68. [English]

Mendel Z, Argaman Q (1986) Discovery of the southern pine beetle, Dendroctonus frontalis, in Israel. Phytoparasitica 14(4): 319-320. doi: 10.1007/BF02980738

Argaman Q (1987a, July) Obituary, Hanan Bytinski-Salz (24 June 1903 - 25 October 1986). Sphecos 14: 17-18.

Argaman Q (1987b, July) Forum: protecting insect collections from pests: what is the best approach? Sphecos 14: 23.

Argaman Q (1987) Sinoxylon anale - a new destructive wood borer in Israel. Phytoparasitica 15(3): 257. doi: 10.1007/bf02979586

Argaman Q, Mendel Z (1987) A representative of the family Scaphidiidae (Insecta: Coleoptera) in Israel. Phytoparasitica 15(3): 257-258. doi: 10.1007/BF02979586

Argaman Q, Mendel Z (1988) Two new species of Rhipiphoridae (Insecta: Coleoptera) in Israel. Phytoparasitica 16(1): 63. doi: 10.1007/bf02979577

Argaman Q (1988a) Generic synopsis of Sclerogibbidae. Annales Historico-Naturales Musei Nationalis Hungarici 80: 177-187.

Argaman Q (1988b, September 20) A new subfamily of Bethylidae allied to Pristocerinae. Bollettino della Società Entomologica Italiana 120(2): 139-152.

Argaman Q (1988c) Description of the female of Ticopla, with biological and taxonomic notes (Hymenoptera, Mutillidae). Fragmenta Balcanica 14(5): 33-46.

Argaman Q, Or R (1988) First record of the family Heteroceridae (Insecta: Coleoptera) in Israel. Phytoparasitica 16(3): 283. 
Argaman Q (1989a, March [“1988”]) Additions to the cynipoid fauna of Israel (Hymenoptera, Cynipoidea). Israel Journal of Entomology 22: 109-117.

Argaman Q (1989b, March) Notes on some western palaearctic Pristocerinae (Hymenoptera, Bethylidae). Revue Suisse de Zoologie 96(1): 9-18.

Argaman Q (1989c) [Family Dryinidae. In: Alon A (Ed.): Plants and Animals of the Land of Israel: An Illustrated Encyclopedia. Vol. 3 Kugler J (Ed.): Insects. p. 335.] [Hebrew]

Argaman Q (1989d) [Family Bethylidae. In: Alon A (Ed.): Plants and Animals of the Land of Israel: An Illustrated Encyclopedia. Vol. 3 Kugler J (Ed.): Insects. p. 335-336.] [Hebrew] Argaman Q (1989e) [Family Chrysididae. In: Alon A (Ed.): Plants and Animals of the Land of Israel: An Illustrated Encyclopedia. Vol. 3 Kugler J (Ed.): Insects. p. 336.] [Hebrew] Argaman Q (1989f) [Family Scoliidae. In: Alon A (Ed.): Plants and Animals of the Land of Israel: An Illustrated Encyclopedia. Vol. 3 Kugler J (Ed.): Insects. p. 337.] [Hebrew] Argaman Q (1989g) [Family Tiphiidae. In: Alon A (Ed.): Plants and Animals of the Land of Israel: An Illustrated Encyclopedia. Vol. 3 Kugler J (Ed.): Insects. p. 338.] [Hebrew]

Argaman Q (1989h) [Family Myzinidae. In: Alon A (Ed.): Plants and Animals of the Land of Israel: An Illustrated Encyclopedia. Vol. 3 Kugler J (Ed.): Insects. p. 338-339.] [Hebrew] Argaman Q (1989i) [Family Mutillidae. In: Alon A (Ed.): Plants and Animals of the Land of Israel: An Illustrated Encyclopedia. Vol. 3 Kugler J (Ed.): Insects. p. 339.] [Hebrew]

Argaman Q, Klein Z, Ben-Dov Y, MendeI Z (1989) [Frankliniella occldentalis (Thysanoptera:

Thripidae), an injurious intruder.] Hassadeh 69(4): 1268-1269 [Hebrew].

Argaman Q (1990a) A synopsis of Perilampus Latreille with descriptions of new genera and species (Hymenoptera: Perilampidae), I. Acta Zoologica Hungarica 36(3-4): 189-263.

Argaman Q \& Mendel Z (1991) [Damages to fruit trees caused by webspinners (Insecta: Embioptera).] Alon HaNotea 1: 29-30. [Hebrew].

Argaman Q, Mendel Z (1991, January) Damage by webspinners (Insecta: Embioptera) in Israel. Tropical Pest Management 37(1): 101.

Argaman Q, Wysoki M (1991, January) The flower-eating Gymnoscelis (Lep. Geometridae) in Israel. Tropical Pest Management 37(2): 185.

Argaman Q (1991a) A synopsis of Perilampus Latreille with descriptions of new genera and species (Hymenoptera: Perilampidae), II. Acta Zoologica Hungarica 37(1-2): 1-19.

Argaman Q (1991b, March [“1990”]) Redescription of Maladera matrida Argaman (Coleoptera: Scarabaeidae: Melolonthinae). Israel Journal of Entomology 24: 21-27.

Argaman Q (1991c, March [“1990”]) Generic synopsis of Sierolomorphidae (Hymenoptera). Israel Journal of Entomology 24: 29-33.

Argaman Q. (1991d [“1990”]) A new predaceous noctuid for Israel (Lepidoptera Noctuidae). Alexanor 16(7): 394.

Argaman Q, Orousset J, Casevitz-Weulersse J (1991 [“1990”]) New pristocerine species for the fauna of France (Hym. Bethylidae Pristocerinae). Entomologica Gallica 2(3): 151-153.

Samish M, Argaman Q, Perelman D (1991) [Hide beetles attacking living turkeys in poultry houses.] Mesheq HaOfot 11: 70-71. [Hebrew]

Samish M, Argamann O [sic] (1991) [Alphitobius diaperinus beetles, a pest in poultry houses.] Hassadeh 72: 387-389. [Hebrew] 
Argaman Q, Özbek H (1992) Reclassification of Tiphiidae (Hymenoptera, Aculeata) with description of a new subfamily from Turkey. Türkiye Entomoloji Dergisi 16(1): 3-12.

Ben-Yehuda S, Izhar Y, Wysoki M, Argaman Q (1992) [Damages caused by Lobesia botrana to pear fruits in Israel.] Alon HaNotea 9: 603-606. [Hebrew]

Argaman Q (1992, March 15) Parasierola swirskiana n. sp. (Hymenoptera: Bethylidae), from the lesser date moth, Batrachedra amydraula Meyrick (Lepidoptera: Batrachedridae). Israel Journal of Entomology 25-26: 195-198.

Samish M, Argaman Q, Perelman D (1992, March) Research note: The hide beetle, Dermestes maculatus DeGeer (Dermestidae), feeds on live turkeys. Poultry Science 71(2): 388-390.

Ben-Yehuda S, Izhar Y, Wysoki M, Argaman Q (1993, April) The grape berry moth, Lobesia botrana Denis \& Schiffermueller (Lepidoptera: Tortricidae), in pear orchards in Israel. International Journal of Pest Management 39(2): 149-151.

Gokkes M, Friedberg A, Klein T, Argaman Q (1993a) [Intrudens leafminer, a new pest of flowers and ornamentals.] Informational Leaflet, Flower Marketing Board, Israel 2: 30. [Hebrew]*

Gokkes M, Friedberg A, Klein T, Argaman Q (1993b) [The South American leafminer, Liriomyza huidobrensis, a new polyphagous pest in Israel.] Hassadeh 74: 194-195. [Hebrew]*

Argaman Q (1993, June 1) Ricerche zoologiche della nave oceanografica "Minerva" (C.N.R.) sulle isole circumsarde. XVI. A taxonomic study of Sclerogibbidae especially from the circumsardinian islands. Annali del Museo Civico di Storia Naturale "Giacomo Doria” 89: 537-553.

Achterberg C van, Argaman Q (1993, July 30) Kollasmosoma gen. nov. and a key to the genera of the subfamily Neoneurinae (Hymenoptera: Braconidae). Zoologische Mededelingen 67(5): 63-74.

Argaman Q (1994a) Generic synopsis of Apterogyninae (Hymenoptera: Apterogynidae). Folia Entomologica Hungarica Rovartani Közlemények 55: 41-58.

Argaman Q (1994b) Generic synopsis of Myzinidae (Hymenoptera: Scolioidea). Annales Historico-Naturales Musei Nationalis Hungarici 86: 85-104.

Argaman Q, Özbek H (1996) A contribution to the knowledge of the eastern Mediterranean Myzinidae I. Subfamily Mesinae Hymenoptera, Aculeata). Turkiye Entomoloji Dergisi 20(4): 245-250.

Argaman Q (1996) Generic synopsis of Scoliidae (Hymenoptera, Scolioidea). Annales Historico-Naturales Musei Nationalis Hungarici 88: 171-222.

Halperin J, Argaman Q (2000) Annotated list of Buprestidae (Coleoptera) and their host plants of Israel. Zoology in the Middle East 20(1): 99-116. doi: 10.1080/09397140.2000.10637819

Argaman Q, Klein Z (2001) The identity of the silverleaf whitefly. In: Abstracts of presentations at the 18th conference of the Entomological Society of Israel. Phytoparasitica 29(1): 75.

Hamburger M, Zarabi L, Weiss M, Argaman Q, Kuslitzky W, Klein Z (2001) False codling moth (Cryptophlebia leucotreta) in Israel. In: Abstracts of presentations at the 18th conference of the Entomological Society of Israel. Phytoparasitica 29(1): 84.

Argaman Q (2002) A new family of the most primitive parasitic aculeate [sic] (Hymenoptera: Aculeata). pp 111-116. In: Parasitic Wasps: Evolution, Systematics, Biodiversity and Biological Control, Melika G, Thurbczy C eds., Agroinform, Budapest, xx + 480 pp.

Argaman Q (2003) Generic synopsis of Mesitinae [sic] Kieffer, 1914 (Hymenoptera: Bethylidae). Entomofauna Zeitschrift für Entomologie 24(4): 61-95. 


\section{Acknowledgements}

This paper was made possible by the support and assistance of David Furth. Additional information and support was provided by Celso Azevedo, Ioana Ciumasu, Chris Darling, Laibale Friedman, Liat Gidron, Venczel Márton, George Melika, Svetlana Nikolaeva, Michael Ohl, Jenő Papp, Roberto Poggi, Zoltán Vas and George Waldren. We also thank the reviewers, Volker Lohrman and Wojciech Pulawski, for their useful suggestions. Additionally, thanks to the staff at the Steinhardt Museum of Natural History, Amnon Freidberg, Laibale Friedman, Moshe Guershon and Netta Dorchin, who are taking care of the Argaman collection.

\section{References}

Ahrens D (2000) Sericinae (Coleoptera: Scarabaeoidea: Melolonthidae) of Arabia. Fauna of Arabia 18: 177-210.

Azevedo CO, Lanes GO (2009) Cladistic assessment and redescription of Galodoxa torquata Nagy (Hymenoptera, Bethylidae), a striking species with swallow tailed metasomal sternite. Zoologische Mededelingen 83(28): 841-851.

Bequaert J (1926) The date of publication of the Hymenoptera and Diptera described by Guérin in Duperrey's "Voyage de La Coquille". Entomologische Mitteilungen 15(2): 186-195.

Betrem [JG] (1926) Verslag [opmerkingen over Scoliiden]. Tijdschrift voor Entomologie 69(1): XII-XIV.

Bohart RM, Menke AS (1976) Sphecid Wasps of the World, A Generic Revision. Berkeley, Los Angeles \& London, 695 pp.

Boni Bartalucci M (2001 ["1999"]) Second contribution to the knowledge of the Old World Myzininae (Hymenoptera: Tiphiidae). Annali del Museo Civico di Storia Naturale "G. Doria" 93: 1-56.

Boni Bartalucci M (2004a, November 30) Tribe-groups of the Myzininae with special regard to the Palearctic taxa of the tribe Meriini (Hymenoptera, Tiphiidae). Linzer Biologische Beiträge 36(2): 1205-1308.

Boni Bartalucci M (2004b) Third contribution to the knowledge of the Old World Myzininae (Hymenoptera, Tiphiidae). Annali del Museo Civico di Storia Naturale "G. Doria" 96: 362-428.

Boni Bartalucci M (2011) Myzininae of the Old World. The subtribe Braunsomeriina (Hymenoptera: Tiphiidae). Linzer Biologische Beiträge 42(1): 363-380.

Bradley JC (1959) The Scoliidae of Africa. Annals of the Transvaal Museum 23(4): 331-362.

Bradley JC (1964) The type-specimens of the Scoliidae described by Amédee [sic] Lepeletier, Comte de Saint-Fargeau (with notes by J.G. Betrem) and by the Marchese Massimiliano Spinola. Annali del Museo Civico di Storia Naturale "Giacomo Doria" 74: 186-196.

Bradley JC, Betrem JG (1966) Burmeister's work on Scoliidae with especial reference to types and synonymy (Hymenoptera: Scoliidae). Beiträge zur Entomologie 16(1/2): 73-84. 
Darling DC (1996) Generic concepts in the Perilampidae (Hymenoptera: Chalcidoidea): an assessment of recently proposed genera. Journal of Hymenoptera Research 5: 100-130.

Elliott MG (2011) Annotated catalogue of the Australian Scoliidae (Hymenoptera). Technical Reports of the Australian Museum, Online 22: 1-17. doi: 10.3853/j.18354211.22.2011.1562

Gordh G, Móczár L (1990) A catalog of the world Bethylidae (Hymenoptera: Aculeata). Memoirs of the American Entomological Institute 46: 1-364.

Guérin-Méneville FC (1838) Genre SCOLIE, Scolia Fabr. In: Duperrey MLI (Ed.) Voyage autour du Monde, exécuté par Ordre du Roi, sur la corvette de Sa Majesté, La Coquille, pendant les années 1822, 1823, 1824 \& 1825. Zoologie (Paris) 2(2, Division 1): 246-255.

Hamon J (1993) Observations sur Scolia (Scolia) galbula (Pallas, 1771), Scolia (Scolia) fallax Eversmann, 1849 et Scolia (Discolia) hirta (Schrank, 1781) (Hymenoptera, Scoliidae). Nouvelle Revue d'Entomologie (Nouvelle Série) 10(1): 87-96.

International Commission on Zoological Nomenclature (ICZN) (1987, June) OPINION 1445. HETEROGYNIDAE Rambur, 1866 (Insecta, Lepidoptera) and HETEROGYNIDAE Nagy, 1969 (Insecta, Hymenoptera): a ruling to remove the homonymy. Bulletin of Zoological Nomenclature 44(2): 150-151.

Jacot-Guillarmod CF, Bradley JC, Betrem JG (1963) Ascoli Guérin-Méneville [sic], 1839 and Ascoli Betrem, 1926 (Insecta, Hymenoptera): proposed rejection as unavailable. Z.N.(S.) 1176. Bulletin of Zoological Nomenclature 20(4): 294-295.

Kimsey LS (2009) Taxonomic purgatory: sorting out the wasp genus Myzinum Latreille in North America (Hymenoptera, Tiphiidae, Myzininae). Zootaxa 2224: 30-50.

Lelej AS, Kabakov ON (1980) [On Bradynobaenidae and Mutillidae (Hymenoptera) of Afghanistan.] Entomologicheskoe Obozrenie 59(1): 181-196. [In Russian; English translation 1981, Entomological Review 59: 141-156]

Lelej AS (2002) Catalogue of the Mutillidae (Hymenoptera) of the Palearctic region. Vladivostok, Dalnauka, $171 \mathrm{pp}$.

Melo GAR (1999) Phylogenetic relationships and classification of the major lineages of Apoidea (Hymenoptera), with emphasis on the crabronid wasps. Scientific Papers, Natural History Museum, the University of Kansas 14: 1-55.

Menke AS (Ed.) (1980) Address changes: Carol G. Nagy. Sphecos 3: 35.

Menke AS (Ed.) (1981) Help needed. Sphecos 4: 2.

Menke AS (Ed.) (1982) People in the news: Qabir Argaman (formerly Carol Nagy Grosman). Sphecos 5: 6.

Menke AS (Ed.) (1987) Research news: Qabir Argaman. Sphecos 14: 3.

Mitchell A, Brothers DJ (1998) Revision and cladistic analysis of the Afrotropical genus Areotilla Bischoff (Hymenoptera: Mutillidae: Ticoplinae). African Entomology 6(2): 193-214.

Mitchell A, Brothers DJ (2002) Phylogeny of the genera of Ticoplinae (Hymenoptera: Mutillidae). Journal of Hymenoptera Research 11(2): 312-325.

Morawitz F (1896, May 26 [“1897”]) Ueber einige transcaspische Raubwespen. Horae Societatis Entomologicae Rossicae 30: 144-160. 
Olmi M (2005 [“2003-2004”]) A revision of the world Sclerogibbidae (Hymenoptera Chrysidoidea). Frustula Entomologica, Nuova Serie 26-27(39-40): 46-193.

Oshanin B (1910) Tables générales des publications de la Société Entomologique de Russie ainsi que des articles, des synopsis et des formes nouvelles y contenues. Horae Societatis Entomologicae Rossicae 8(Suppl.): 1-282.

Osten T (1997) Zur Taxonomie von Scolia (Discolia) mongolina Nagy, 1970 und Scolia (Scolia) incana Nagy, 1970 (Hymenoptera, Scoliidae). Entomofauna Zeitschrift für Entomologie 18(31): 513-520.

Osten T (2002) Beitrag zur Kenntnis der Scoliidenfauna von Israel (Hymenoptera, Scoliidae). Entomofauna Zeitschrift für Entomologie 23(28): 337-352.

Osten T (2005) Checkliste der Dolchwespen der Welt (Insecta: Hymenoptera, Scoliidae). Bericht der Naturforschenden Gesellschaft Augsburg 62: 1-62.

Pagliano G (2002) Revisione della sottofamiglia Apterogyninae (Hymenoptera: Bradynobaenidae). Museo Regionale di Scienze Naturali di Torino, Monografie 34: 1-388.

Perrichot V, Nel A (2008) Eocene bethylid wasps from French amber (Hymenoptera: Bethylidae). Neues Jahrbuch für Geologie und Paläontologie Abhandlungen 248(1): 91-101. doi: 10.1127/0077-7749/2008/0248-0091

Romano M (2012) Nanomutilla vaucheri in Sardegna, prima segnalazione per l'Italia (Hymenoptera Mutillidae). Bollettino della Società Entomologica Italiana 144(1): 23-27. doi: 10.4081/BollettinoSEI.2012.23

Saussure H de, Sichel J (1864) Catalogue des espèces de l'ancien genre Scolia, contenant les diagnoses, les descriptions et la synonymie des espèces, avec des remarques explicatives et critiques. Geneva \& Paris, 350 pp., 2 pl.

Turner RE (1912) Studies in the fossorial wasps of the family Scoliidae, subfamilies Elidinae and Anthoboscinae. Proceedings of the Zoological Society of London 1912(3): 696-754, pl. LXXXI-LXXXIII.

Yildirim E, Boni Bartalucci M (2009) Tiphiidae (Hymenoptera, Aculeata) of Turkey. Linzer Biologische Beiträge 41(2): 2051-2065. 


\section{Appendix I}

New taxa described and new names proposed by Argaman/Nagy. It has not been possible to check the accuracy of all of Argaman/Nagy's type designations, so the information on these is derived directly from his publications. Synonymies have been indicated where known to us; some may, however, have been missed, so this listing should not be considered authoritative.

\section{Order Hymenoptera}

\section{Family Ampulicidae}

Species:

Chlorampulex sciophanes Nagy, 1971c: 104. Holotype male; Formosa (Taiwan): Takao (Nagy Coll.). =Ampulex sciophanes $($ Nagy). Transferred by Bohart \& Menke (1976: 78).

Dolichurus alorus Nagy, 1971c: 106. Holotype male; Formosa (Taiwan): Taihorin (Nagy Coll.).

Dolichurus dromedarius Nagy, 1971c: 106. Holotype male; Formosa (Taiwan): Takao (Nagy Coll.).

Dolichurus ombrodes Nagy, 1971c: 106. Holotype male; Formosa (Taiwan): Taihorin (Nagy Coll.).

Dolichurus oxanus Nagy, 1971c: 107. Holotype male; Celebes (Sulawesi): BuaKraeng (Nagy Coll.).

Family Bradynobaenidae, Subfamily Apterogyninae [treated as Family Apterogynidae by Argaman]

Tribe: Doryleikini Argaman, 1994a: 45. Type genus: Doryleika Argaman, 1994. =Apterogyninae André, 1899. Synonymy implied by Pagliano (2002) in not recognizing higher taxa within Apterogyninae.

Tribe: Gynecapterini Argaman, 1994a: 46. Type genus: Gynecaptera Skorikov, 1935. =Apterogyninae André, 1899. Synonymy implied by Pagliano (2002) in not recognizing higher taxa within Apterogyninae.

Tribe: Icalanticini Argaman, 1994a: 47. Type genus: Icalantica Argaman, 1994. =Apterogyninae André, 1899. Synonymy implied by Pagliano (2002) in not recognizing higher taxa within Apterogyninae.

Tribe: Pauxorculini Argaman, 1994a: 48. Type genus: Pauxorcula Argaman, 1994. =Apterogyninae André, 1899. Synonymy implied by Pagliano (2002) in not recognizing higher taxa within Apterogyninae.

Genus: Doryleika Argaman, 1994a: 46. Type species: Doryleika mahunkai Argaman, 1994. = Macroocula Panifilov, 1954. Synonymized by Pagliano (2002: 125).

Genus: Icalantica Argaman, 1994a: 48. Type species: Apterogyna lateritia Morawitz, 1890. = Apterogyna Latreille, 1809. Synonymized by Pagliano (2002: 26). 
Genus: Micatagla Argaman, 1994a: 45. Type species: Apterogyna schultzei André, 1909.

Genus: Mutillariola Argaman, 1994a: 47. Type species: Apterygyna bimaculata André, 1898. = Gynecaptera Skorikov, 1935. Synonymized by Pagliano (2002: 101).

Genus: Pauxorcula Argaman, 1994a: 49. Type species: Apterogyna bulawayona Peringuey, 1914. = Micatagla Argaman, 1994. Synonymized by Pagliano (2002: 204).

Genus: Utapitoca Argaman, 1994a: 48. Type species: Apterogyna latreillei Klug, 1829. = Apterogyna Latreille, 1809. Synonymized by Pagliano (2002: 26).

Genus: Zarabayca Argaman, 1994a: 49. Type species: Apterogyna miniaticornis Enderlein, 1901. = Apterogyna Latreille, 1809. Synonymized by Pagliano (2002: 26).

Species:

Doryleika mahunkai Argaman, 1994a: 51. Holotype male; Tunisia: Boughrara (Budapest, confirmed). =Macroocula mahunkai (Argaman). Transferred by Pagliano (2002: 160).

\section{Family Bethylidae}

Subfamily: Afgoiogfinae Argaman, 1988b: 140. Type genus: Afgoiogfa Argaman, 1988. = Pristocerinae Dalla Torre, 1898. Synonymy implied by Gordh \& Moczar (1990: 198) in placing Afgoiogfa Argaman in Pristocerinae.

Subfamily: Galodoxinae Nagy, 1974c: 126. Type genus: Galodoxa Nagy, 1974. =Epyrinae Kieffer, 1914. Synonymized by Azevedo \& Lanes (2009: 847).

Subfamily: Protopristocerinae Nagy, 1974c: 126. Type genus: Protopristocera Brues, 1923. =Pristocerinae Dalla Torre, 1898. Synonymy implied by Perrichot \& Nel (2008: 101) in placing Protopristocera Brues in Pristocerinae.

Tribe: Domonkosini Argaman, 2003: 66, 79. Type genus: Domonkos Argaman, 2003. = Mesitiinae Kieffer, 1914. Synonymy implied by Gordh \& Moczar (1990) in not recognizing higher taxa within Mesitiinae.

Tribe: Heterocoeliini Argaman, 2003: 66, 67. Type genus: Heterocoelia Dahlbom, 1854. =Mesitiinae Kieffer, 1914. Synonymy implied by Gordh \& Moczar (1990) in not recognizing higher taxa within Mesitiinae.

Tribe: Triglenusini Argaman, 2003: 66, 72. Type genus: Triglenus Marshall, 1905. =Mesitiinae Kieffer, 1914. Synonymy implied by Gordh \& Moczar (1990) in not recognizing higher taxa within Mesitiinae.

Genus: Afgoiogfa Argaman, 1988b: 141. Type species: Afgoiogfa olmiana Argaman, 1988.

Genus: Botoryan Argaman, 2003: 66, 69. Type species: Mesitius discolor Nagy, 1968. Genus: Clytrovorus Nagy, 1972a: 10. Type species: Mesitius horvathi Kieffer, 1906. Genus: Codorcas Nagy, 1972a: 10. Type species: Mesitius cursor Kieffer, 1906.

Genus: Domonkos Argaman, 2003: 67, 79. Type species: Mesitius capensis Kieffer, 1911.

Genus: Galodoxa Nagy, 1974c: 126. Type species: Galodoxa torquata Nagy, 1974. 
Genus: Gerbekas Argaman, 2003: 66, 71. Type species: Mesitius carcelii Westwood, 1874.

Genus: Hamusmus Argaman, 2003: 66, 72. Type species: Mesitius punctatus Kieffer, 1906

Genus: Itapayos Argaman, 2003: 67, 77. Type species: Mesitius spinosus Kieffer, 1906.

Genus: Topcobius Nagy, 1972a: 17. Type species: Mesitius punctaticollis Fouts, 1930.

Genus: Ukayakos Argaman, 2003: 66, 68. Type species: Mesitius obscurus Kieffer, 1906.

Genus: Zimankos Argaman, 2003: 67, 80. Type species: Mesitius alluaudi Kieffer, 1913.

Species:

Afgoiogfa olmiana Argaman, 1988b: 143. Holotype male; Somalia: Afgoi (Pagliano Coll.).

Bethylus antipai Nagy, 1968h: 1033. Holotype male; Romania: Bistriţa, Station de Recherches Biologiques d'Arcalia (Nagy Coll.).

Bethylus paradoxus Nagy, 1970e: 63. Holotype female; Romania: Cluj, Fînaţele Clujului (Nagy Coll.)

Dissomphalus claudivani Argaman, 1989b: 9. Holotype female; Israel: Galilea, below Safad (Geneva).

Epyris carbunculus Nagy, 1970j: 267. Holotype male; Romania: Agigea (Tel Aviv [Nagy Coll.], confirmed).

Galodoxa torquata Nagy, 1974c: 127. Holotype female; Philippines: Palawan, Mantalingajan, Pinigisan 600m (Copenhagen, confirmed).

Holepyris napocaensis Nagy, 1968g: 409. Holotype male; Romania: Cluj (Nagy Coll.)

Mesitius andriescui Nagy, 1970c: 207. Holotype female; Morocco: "Tanger" (Geneva).

Mesitius bridwelli Nagy, 1968a: 170. Holotype female; Nigeria: Lagos (Washington, confirmed).

Mesitius caspicus Nagy, 1969i: 291. Holotype female; "Umgebung des Kaspischen Meeres" (Paris, confirmed).

Mesitius cerasinus Nagy, 1970c: 208. Holotype female; Morocco: "Maroc" (Geneva).

Mesitius clavicornis Nagy, 1968a: 173. Holotype female: India (Nagy Coll., Tel Aviv, confirmed).

Mesitius concii Nagy, 1972a: 8. Holotype male; Spain: "Palma de Mallorca" (Nagy Coll.).

Mesitius discolor Nagy, 1968a: 174. Holotype male; Country?: "Arallan or Arauan" (Washington).

Mesitius foenarius Nagy, 1968a: 171. Holotype female; Romania: Cluj (Nagy Coll.). Mesitius kiefferi Nagy, 1970g: 205. Holotype male; Algeria: Bildah-Médéah (Berlin). 
Mesitius krombeini Nagy, 1968a: 175. Holotype male; India: Mangalore (Washingon).

Mesitius moczari Nagy, 1968a: 172. Holtoype female; Afghanistan: KandaharKuna (Budapest).

Mesitius orcus Nagy, 1972a: 9. Holotype male; Israel: "Palestina" (Nagy Coll.).

Mesitius viator Nagy, 1968a: 171. Holotype female; Russia: Sarepta (Berlin, confirmed).

Parascleroderma cisnora Argaman, 1988b: 147. Holotype male; West Bank: Bethlehem, Wadi-Tekoa (Argaman Coll.)

Parascleroderma fiturcata Argaman, 1988b: 150. Holotype male; Italy: Napoli, Volcano Stromboli (Argaman Coll.)

Parascleroderma hindola Argaman, 1988b: 151. Holotype male; Israel: TellZakarja Junction (Argaman Coll.)

Parascleroderma norcasta Argaman, 1988b: 147. Holotype male; Italy: Liguria, Savona (Argaman Coll.)

Parascleroderma oriana Argaman, 1988b: 148. Holotype male; Israel: Hawwat Eden (Argaman Coll.)

Parascleroderma varlinda Argaman, 1988b: 148. Holotype male; Israel: Sharon Plain, Hofit, Nahal Alexander (Argaman Coll.)

Parasierola swirskiana Argaman, 1992: 195. Holotype female; Israel: Central coastal plain, Mikhmoret, Miramare hotel garden (Tel Aviv, confirmed).

Sulcomesitius hilarius Nagy, 1972a: 16. Holotype female; Ethiopia: "N. Galla, Aberasch" (Tel Aviv [Nagy Coll.], confirmed).

Subspecies:

Mesitius africanus lugubris Nagy, 1970c: 207. Holotype female; Morocco: Tangier (Geneva).

\section{Family Braconidae}

Genus: Kollasmosoma Achterberg \& Argaman, 1993: 64, 66. Type species: Elasmosoma platamonense Huddleston, 1976.

\section{Family Dryinidae}

Species:

Bocchus scobiolae Nagy, 1967e: 334. Holotype female; Romania: Agigea, Dobroudja (Tel Aviv, confirmed).

Bocchus pedunculatus Nagy, 1969e: 323. Holotype male; Philippines: Palawan, Pinigisan, Mantalingajan (Copenhagen, confirmed).

Family: Heterogynaidae Nagy, 1969b: 299. [Emended from Heterogynidae by ICZN (1987), nec Heterogynidae, Lepidoptera]. Type genus: Heterogyna Nagy, 1969. Genus: Daycatinca Argaman, 1986a: 7. Type species: Heterogyna fantsilotra Day, 1984. = Heterogyna Nagy, 1969. Synonymized by Melo (1999: 34).

Genus: Heterogyna Nagy, 1969b: 300. Type species: Heterogyna protea Nagy, 1969. 
Species:

Heterogyna kugleri Argaman, 1986a: 8. Holotype female; Israel: Nazareth (Argaman Coll.).

Heterogyna protea Nagy, 1969b: 300. Holotype male; Greece: Rhodes, Ixia (Nagy Coll.?).

Family: Kislevidae Argaman, 2002. Type genus: Kisleva Argaman, 2002.

Genus: Kisleva Argaman, 2002: 112. Type species: Kisleva ohalona Argaman, 2002.

Species:

Kisleva ohalona Argaman, 2002: 112. Holotype subfossil head; Israel: Galilee, Locus No. 1, Ohalo II excavation (Bar Ilan).

\section{Family Mutillidae}

Subfamily: Ticoplinae Nagy, 1970f: 84. Type genus: Ticopla Nagy, 1970.

Tribe: Smicromyrmillini Argaman, 1988c: 36. Type genus: Smicromyrmilla Suárez, 1965.

Tribe: Ticoplini Nagy, 1970f: 84. Type genus: Ticopla Nagy, 1970.

Genus: Ticopla Nagy, 1970f: 85. Type species: Ticopla yoca Nagy, 1970. $=N a-$ nomutilla André, 1900. Synonymized by Mitchell and Brothers (1998: 193 \& 2002: 313).

Subgenus: Arcasina Nagy, 1970g: 88, 95. Type species: Ephuta (Arcasina) chendisa Nagy, 1970.

Subgenus: Rhombotilla Nagy, 1966a: 113. Type species: Smicromyrme (Rhombotilla) riparia Nagy, 1966.

Species:

Dolichomutilla cribraria Nagy, 1968b: 147. Holotype female; Sudan: Khartoum ("Chartoum") (Cluj?).

Ephuta (Arcasina) chendisa Nagy, 1970g: 88, 96. Holotype male; Surinam (Nagy Coll.).

Ephuta (Ephuta) anephuta Nagy, 1970g: 88, 92. Holotype female; Brazil: Santa Catarina, Boiteuxburgo (Hamburg).

Ephuta (Ephuta) bilunata Nagy, 1970g: 87, 89. Holotype female; Brazil: São Paulo, Estancio Mayrink (Hamburg).

Ephuta (Ephuta) buftex Nagy, 1970g: 88, 91. Holotype female; Brazil: São Paulo, Estancio Mayrink (Hamburg).

Ephuta (Ephuta) bulmaca Nagy, 1970g: 88, 93. Holotype male; Brazil: São Paulo, Estancio Mayrink (Hamburg).

Ephuta (Ephuta) cumba Nagy, 1970g: 88, 90. Holotype female; Brazil: Rio de Janeiro, Petropolis (Hamburg).

Ephuta (Ephuta) dorida Nagy, 1970g: 88, 93. Holotype male; Costa Rica: "Pacific-Seite" (Hamburg). 
Ephuta (Ephuta) elanora Nagy, 1970g: 88, 94. Holotype male; Costa Rica: San José de Costa Rica (Hamburg).

Ephuta (Ephuta) minerva Nagy, 1970g: 88, 93. Holotype male; Brazil: São Paulo, Estancio Mayrink (Hamburg).

Ephuta (Ephuta) novacula Nagy, 1970g: 88, 90. Holotype female; Brazil: São Paulo (Nagy Coll.).

Ephuta (Ephuta) olma Nagy, 1970g: 88, 92. Holotype male; Brazil: Rio Grande do Sul, Santa Cruz (Hamburg).

Ephuta (Ephuta) serapia Nagy, 1970g: 89, 95. Holotype male; Costa Rica: "Pacific-Seite" (Hamburg).

Ephuta (Ephuta) sicona Nagy, 1970g: 87, 89. Holotype female; Ecuador: Guyaquil (Nagy Coll.).

Ephuta (Ephuta) verbena Nagy, 1970g: 89, 94. Holotype male; Costa Rica: San José de Costa Rica (Hamburg).

Ephuta (Ephuta) weidneri Nagy, 1970g: 87, 89. Holotype female; Brazil: São Paulo (Hamburg).

Ephuta (Ephuta) yarasirda Nagy, 1970g: 88, 92. Holotype male; Argentina: District Mendoza (Hamburg).

Myrmilla atalanta Nagy, 1967b:52. Holotype male; Romania: Dobroutcha, "dunes maritimes d'Agigea" (Nagy Coll.). =Myrmilla (Pseudomutilla) atalanta Nagy. Subgenus specified by Lelej (2002: 36).

Myrmilla labecua Nagy, 1968c: 68. Holotype female; Romania: Cluj (Nagy Coll.). Myrmilla macrura Nagy, 1968c: 65. Holotype female; Romania: Cluj (Nagy Coll.).

Nanomutilla nadae Argaman, 1988c: 38. Holotype female; south Spain (Argaman Coll.). Spelling of specific name fixed by Mitchell $\&$ Brothers (2002: 313).

Smicromyrme borceai Nagy, 1968f: 220. Holotype female; Romania: Agigea (Nagy Coll.). Placed in subgenus Erimyrme Lelej, 1985 by Lelej (2002: 68). Smicromyrme (Edrionotus) ursina Nagy, 1972c: 4. Holotype female; Turkey: Ankara, Salt Lake (Tuz-Gölü) (Nagy Coll.). =Dentilla ursina (Nagy). Transferred by Lelej \& Kabakov (1980: 195).

Smicromyrme (Rhombotilla) riparia Nagy, 1966a: 115. Holotype female; Romania: Agigea (Nagy Coll.).

Smicromyrme (Rhombotilla) vinuta Nagy, 1972c: 5. Holotype male; Afghanistan, Kabul vicinity (Nagy Coll.). =Promecilla vinuta (Nagy). Transferred by Lelej \& Kabakov (1980: 192).

Smicromyrme (Smicromyrme) terricola Nagy, 1972b: 29. Holotype female; Greece: "Nea Peramos" (Nagy Coll.). Considered incertae sedis by Lelej (2002: 79).

Smicromyrme (Smicromyrme) tumidula Nagy, 1972b: 27. Holotype female; Greece: "Parnals" (Nagy Coll.). Considered incertae sedis by Lelej (2002: 79). 
Smicromyrme (Smicromyrme) weidneri Nagy, 1971a:167. Holotype female: Iran ("Persien") (Hamburg, confirmed). =Dentilla weidneri (Nagy). Transferred by Lelej \& Kabakov (1980: 195).

Ticopla parila Nagy, 1970f: 85. Holotype male; Jordan: Amman (Nagy Coll.). $=$ Nanomutilla parila $(\mathrm{Nagy})$. Transfer implied by Mitchell $\&$ Brothers (2002: 313).

Ticopla yoca Nagy, 1970f: 85. Holotype male; Jordan (Nagy Coll.) =Nanomutilla yoca (Nagy). Transferred by Mitchell \& Brothers (2002: 313).

\section{Family Perilampidae}

Genus: Bagdasar Argaman, 1990a: 212, 250. Type species: Bagdasar amnonius Argaman, 1990. = Perilampus Latreille, 1809. Synonymized by Darling (1996: 120).

Genus: Balintos Argaman, 1990a: 205, 241. Type species: Perilampus parvus Howard, 1896. = Perilampus Latreille, 1809. Synonymized by Darling (1996: 107).

Genus: Bukbakas Argaman, 1990a: 229, 261. Type species: Perilampus microgastris Ferrière, 1930. =Perilampus Latreille, 1809. Synonymized by Darling (1996: 126).

Genus: Dekterek Argaman, 1990a: 230, 262. Type species: Perilampus granulosus Crawford, 1914. = Perilampus Latreille, 1809. Synonymized by Darling (1996: 124). Genus: Durgadas Argaman, 1990a: 205, 239. Type species: Durgadas pappi Argaman, 1990. =Perilampus Latreille, 1809. Synonymized by Darling (1996: 114).

Genus: Ecalibur Argaman, 1990a: 228, 260. Type species: Perilampus robertsoni Crawford, 1914. = Perilampus Latreille, 1809. Synonymized by Darling (1996: 122).

Genus: Fifirtiz Argaman, 1990a: 225, 259. Type species: Perilampus noemi Nikolskaya, 1952. =Perilampus Latreille, 1809. Synonymized by Darling (1996: 117).

Genus: Fulaytar Argaman, 1990a: 208, 243. Type species: Perilampus singaporensis Rohwer, 1923. =Perilampus Latreille, 1809. Synonymized by Darling (1996: 110).

Genus: Goyurfis Argaman, 1990a: 205, 242. Type species: Perilampus platigaster Say, 1836. =Perilampus Latreille, 1809. Synonymized by Darling (1996: 114). Genus: Ihrambek Argaman, 1990a: 213, 252. Type species: Perilampus chrysonotus Foerster, 1859. =Perilampus Latreille, 1809. Synonymized by Darling (1996: 124; misspelled as Ihambrek).

Genus: Itonayis Argaman, 1990a: 211, 248. Type species: Perilampus micans Dalman, 1820. =Perilampus Latreille, 1809. Synonymized by Darling (1996: 119).

Genus: Kekender Argaman, 1990a: 201, 233. Type species: Kekender bouceki Argaman, 1990. =Perilampus Latreille, 1809. Synonymized by Darling (1996: 107).

Genus: Lufarfar Argaman, 1990a: 232; 1991a: 3. Type species: Lufarfar rainerius Argaman, 1990. = Perilampus Latreille, 1809. Synonymized by Darling (1996: 125).

Genus: Mivarhis Argaman, 1990a: 219, 255. Type species: Perilampus laevifrons Dalman, 1822. =Perilampus Latreille, 1809. Synonymized by Darling (1996: 127).

Genus: Naspoyar Argaman, 1990a: 228, 261. Type species: Perilampus fulvicornis Ashmead, 1886. =Perilampus Latreille, 1809. Synonymized by Darling (1996: 121). 
Genus: Nilgator Argaman, 1990a: 207, 242. Type species: Perilampus mirabeaui Girault, 1930. = Perilampus Latreille, 1809. Synonymized by Darling (1996: 108).

Genus: Olarlar Argaman, 1990a: 214, 252. Type species: Chalcis aenea Rossi, 1790 and Olarlar cocegus Argaman, 1990. Chalcis aenea Rossi was designated as the type species by Darling (1996: 114, 116). =Perilampus Latreille, 1809. Synonymized by Darling (1996: 116).

Genus: Pondoros Argaman, 1990a: 230; 1991a: 1. Type species: Perilampus tristis Mayr, 1905. = Perilampus Latreille, 1809. Synonymized by Darling (1996: 125).

Genus: Sicatang Argaman, 1990a: 225, 257. Type species: Sicatang catilus Argaman, 1990. =Perilampus Latreille, 1809. Synonymized by Darling (1996: 117).

Genus: Taltonos Argaman, 1990a: 201, 234. Type species: Perilampus hyalinus Say, 1828. = Perilampus Latreille, 1809. Synonymized by Darling (1996: 113).

Genus: Tiboras Argaman, 1990a: 208, 243. Type species: Perilampus maurus Walker, 1852. = Perilampus Latreille, 1809. Synonymized by Darling (1996: 110).

Genus: Tondolos Argaman, 1990a: 208, 243. Type species: Perilampus tasmanicus Cameron, 1911. =Perilampus Latreille, 1809. Synonymized by Darling (1996: 110).

Genus: Vadramas Argaman, 1990a: 223, 255. Type species: Perilampus nigriviridis Girault, 1912. =Perilampus Latreille, 1809. Synonymized by Darling (1996: 116).

Genus: Vaktaris Argaman, 1990a: 211, 248. Type species: Cynips auratus Panzer, 1798. = Perilampus Latreille, 1809. Synonymized by Darling (1996: 119).

Genus: Yertatop Argaman, 1990a: 207, 242. Type species: Perilampus emersoni Girault, 1930. =Perilampus Latreille, 1809. Synonymized by Darling (1996: 107).

Genus: Zuglavas Argaman, 1990a: 212, 251. Type species: Perilampus stygicus Provancher, 1888. =Perilampus Latreille, 1809. Synonymized by Darling (1996: 122).

Species:

Afroperilampus delbotor Argaman, 1990a: 211, 247. Holotype female; Uganda: Mujenje (Budapest, confirmed). =Perilampus delbotor (Argaman). Transfer implied by Darling (1996: 111, 127).

Afroperilampus horocos Argaman, 1990a: 210, 246. Holotype male; "Africa Or.[ientale]": Arusha (Budapest, confirmed). =Perilampus horocos (Argaman). Transfer implied by Darling (1996: 111, 127).

Afroperilampus hurap Argaman, 1990a: 209, 245. Holotype female; Uganda: Bussu (Genoa, confirmed). =Perilampus hurap (Argaman). Transfer implied by Darling (1996: 111, 127).

Afroperilampus liliae Argaman, 1990a: 210, 245. Holotype male; Algeria: Biskra (Genoa, confirmed). =Perilampus liliae (Argaman). Transfer implied by Darling (1996: 111, 127).

Bagdasar amnonius Argaman, 1990a: 212, 251. Holotype female; South Africa: Natal, Pietermaritzburg, Ashburton (Argaman Coll.). =Perilampus amnonius (Argaman). Transfer implied by Darling (1996: 120). 
Bukbakas casevitzi Argaman, 1990a: 229, 262. Holotype male; South Africa: Pretoria (Argaman Coll.). =Perilampus casevitzi (Argaman). Transfer implied by Darling (1996: 126).

Durgadas pappi Argaman, 1990a: 205, 239. Holotype female; Brazil: Para, Rio Acara (Budapest, confirmed). =Perilampus pappi (Argaman). Transfer implied by Darling (1996: 114).

Fifirtiz mavricus Argaman, 1990a: 227, 260. Holotype female; Egypt: "H.-I. Sinai, Ofira" (Argaman Coll.). =Perilampus mavricus (Argaman). Transfer implied by Darling (1996: 117).

Fifirtiz turpiculus Argaman, 1990a: 226, 259. Holotype male; Israel: Upper Galilee, Hula Valley Natural Reserve (Argaman Coll.).=Perilampus turpiculus (Argaman). Transfer implied by Darling (1996: 117).

Goyurfis dobnos Argaman, 1990a: 199. New replacement name for Perilampus antennatus Cameron, 1897 nec Perilampus antennatus Walker, 1834. =Perilampus dobnos (Argaman). Transfer implied by Darling (1996: 114).

Kekender bouceki Argaman, 1990a: 201, 233. Holotype male; Kenya: MutoBerg (Argaman Coll.). =Perilampus bouceki (Argaman). Transfer implied by Darling (1996: 107).

Lufarfar nimrodus Argaman, 1990a: 232; 1991a: 4. Holotype female; "Africa or.[ientale]": Assab (Budapest, confirmed). =Perilampus nimrodus (Argaman). Transfer implied by Darling (1996: 125).

Lufarfar rainerius Argaman, 1990a: 232; 1991a: 4. Holotype female; Egypt: Gebel Asfar (Genoa, confirmed). =Perilampus rainerius (Argaman). Transfer implied by Darling (1996: 125).

Olarlar cocegus Argaman, 1990a: 214, 252. Holotype female; South Africa: "Meester-Cornelis, Transvaal" (Argaman Coll.). =Perilampus cocegus (Argaman). Transfer implied by Darling (1996: 116).

Perilampus uris Argaman, 1990a: 199. New replacement name for Perilampus carinifrons Mani et Kaul, 1973 nec Perilampus carinifrons Crawford, 1914.

Pondoros kittenbergeri Argaman, 1990a: 230; 1991a: 2. Holotype female; Uganda: Mujenje (Budapest, confirmed). =Perilampus kittenbergeri (Argaman). Transfer implied by Darling (1996: 125).

Pondoros moczari Argaman, 1990a: 232; 1991a: 2. Holotype female; Afghanistan: Nuristan, Bashgul-Tal, Achmede Dewane (Budapest, confirmed). =Perilampus moczari (Argaman). Transfer implied by Darling (1996: 125).

Sicatang catilus Argaman, 1990a: 225, 258. Holotype male; Turkey: Anatolia, "Tschukur-hissar" (Argaman Coll.). =Perilampus catilus (Argaman). Transfer implied by Darling (1996: 117).

Sicatang picpus Argaman, 1990a: 225, 258. Holotype female; Korea: Gangvon, Ondzong, Kum-gang san, along Ok-ru dong (Budapest, confirmed). =Perilampus picpus (Argaman). Transfer implied by Darling (1996: 117).

Taltonos azureus Argaman, 1990a: 203, 235. Holotype female; Argentina: Tucuman (Budapest, confirmed). =Perilampus azureus (Argaman). Transfer implied by Darling (1996: 113). 
Taltonos birous Argaman, 1990a: 203, 237. Holotype female; Brazil: Santa Cruz (Budapest, confirmed). =Perilampus birous (Argaman). Transfer implied by Darling (1996: 113).

Taltonos dumcas Argaman, 1990a: 203, 236. Holotype female; Argentina: Tucuman (Budapest, confirmed). =Perilampus dumcas (Argaman). Transfer implied by Darling (1996: 113).

Taltonos jolaus Argaman, 1990a: 204, 238. Holotype female; [Brazil:] Sao Paulo (Budapest, confirmed). =Perilampus jolaus (Argaman). Transfer implied by Darling (1996: 113).

Taltonos sirsiris Argaman, 1990a: 199. New replacement name for Perilampus cyaneus Brullé, 1846 nec Perilampus cyaneus Fabricius, 1798. =Perilampus sirsiris (Argaman). Transfer implied by Darling (1996: 113).

Taltonos tutubas Argaman, 1990a: 202, 235. Holotype female; Argentina: Mendoza (Budapest, confirmed). =Perilampus tutubas (Argaman). Transfer implied by Darling (1996: 113).

Taltonos xirgus Argaman, 1990a: 203, 236. Holotype male; Brazil: Para, Faro (Budapest, confirmed). =Perilampus xirgus (Argaman). Transfer implied by Darling (1996: 113).

Vadramas tetar Argaman, 1990a: 225, 257. Holotype male; Nicaragua: "Sierra di Managua" (Genoa, confirmed). =Perilampus tetar (Argaman). Transfer implied by Darling (1996: 116).

Vaktaris ganuz Argaman, 1990a: 212, 249. Holotype male; Israel: near Dead Sea (Tel Aviv). =Perilampus ganuz (Argaman). Transfer implied by Darling (1996: 119).

Vaktaris ilvauber Argaman, 1990a: 211, 249. Holotype female; Guatemala: Punta Gorda (Argaman Coll.). = Perilampus ilvauber (Argaman). Transfer implied by Darling (1996: 119).

\section{Family Plumariidae}

Species:

Plumarius argentinus Nagy, 1973c: 259, 266. Holotype male; Argentina: Rio Negro, Norquinco (Budapest, confirmed).

Plumarius baloghi Nagy, 1973c: 258, 259. Holotype male; Chile: Tarapaca Prov., Azapa (Budapest, confirmed).

Plumarius chilensis Nagy, 1973c: 258, 262. Holotype male; Chile: Tarapaca Prov., Azapa (Budapest, confirmed).

Plumarius densepunctatus Nagy, 1973c: 259, 265. Holotype male; Chile: Coquimbo Prov., El Tangue (Nagy Coll.).

Plumarius topali Nagy, 1973c: 258, 260. Holotope male; Argentina: Rio Negro, Norquinco (Budapest, confirmed). 


\section{Family Sclerogibbidae}

Subfamily: Caenosclerogibbinae Argaman, 1988a: 178. Type genus Caenosclerogibba Yasumatsu, 1958. =Sclerogibbidae Ashmead, 1902. Synonymy implied by Olmi (2005) in not recognizing higher taxa within Sclerogibbidae.

Subfamily: Probethylinae Argaman, 1988a: 178. Type genus Probethylus Ashmead, 1902. =Sclerogibbidae Ashmead, 1902. Synonymy implied by Olmi (2005) in not recognizing higher taxa within Sclerogibbidae.

Tribe: Tanynotini Argaman, 1988a: 178. Type genus Tanynotus Cameron, 1904. =Sclerogibbidae Ashmead, 1902. Synonymy implied by Olmi (2005) in not recognizing higher taxa within Sclerogibbidae.

Tribe: Parasclerogibbini Argaman, 1988a: 178. Type genus Parasclerogibba Hamann, 1958. =Sclerogibbidae Ashmead, 1902. Synonymy implied by Olmi (2005) in not recognizing higher taxa within Sclerogibbidae.

Genus: Poggiana Argaman, 1993: 540, 541. Type species: Poggiana pilosella Argaman, 1993. =Sclerogibba Riggio \& De Stefani-Perez, 1888. Synonymized by Olmi (2005: 120).

Species:

Poggiana pilosella Argaman, 1993: 543. Holotype female; Italy: Sardinia, Tavolara Archipelago, Isola Molarotto (Genoa, confirmed). =Sclerogibba berlandi Benoit, 1963. Synonymized by Olmi (2005: 129).

Prosclerogibba dessarti Argaman, 1993: 550. Holotype male; Togo: Sokode (Brussels, confirmed). =Sclerogibba vagabunda (Bridwell, 1919). Synonymized by Olmi (2005: 180).

\section{Family Scolebythidae}

Genus: Ycaploca Nagy, 1975c: 75. Type species: Ycaploca evansi Nagy, 1975. Species:

Ycaploca evansi Nagy, 1975c: 75. Holotype female; South Africa: Cape, Kirstenbosch (Nagy Coll.).

Family Scoliidae (Argaman (1996) was deliberately not taken into account by Osten (2005) in compiling his checklist of Scoliidae of the world. Elliott (2011) recognized that Osten (2005) implicitly synonymized some Argaman genera by placing their type species in other genera or subgenera, and we have followed this approach, although some of Argaman's type species may have been misidentified since he did not examine their type material. Argaman's (1996) numerous new names and other nomenclatural acts thus still need more critical evaluation beyond that possible here.)

Subfamily: Colpinae Argaman, 1996: 180. Type genus: Colpa Dufour, 1841. =Campsomerini Betrem in Betrem \& Bradley, 1972. Synonymy implied by Osten (2005: 3).

Tribe: Agombardini Argaman, 1996: 193. Type genus: Agombarda Argaman, 1996. =Scoliini Latreille, 1802. Synonymy implied by Osten (2005: 27). 
Tribe: Ascoliini Argaman, 1996: 187. Type genus: Ascolia Argaman, 1996. =Scoliini Latreille, 1802. Synonymy implied by Osten (2005: 37).

Tribe: Austroscoliini Argaman, 1996: 191. Type genus: Austroscolia Betrem, 1928. =Scoliini Latreille, 1802. Synonymy implied by Osten (2005: 26).

Tribe: Betremiini Argaman, 1996: 197. Type genus: Betremia Bradley, 1948. =Scoliini Latreille, 1802. Synonymy implied by Osten (2005: 26).

Tribe: Carinoscoliini Argaman, 1996: 191. Type genus: Carinoscolia Betrem, 1927. =Scoliini Latreille, 1802. Synonymy implied by Osten (2005: 26).

Tribe: Colpacampsomerini Argaman, 1996: 209. Type genus: Colpacampsomeris Betrem, 1941. =Campsomerini Betrem in Betrem \& Bradley, 1972. Synonymy implied by Osten (2005: 3).

Tribe: Colpini Argaman, 1996: 184. Type genus: Colpa Dufour, 1841. =Campsomerini Betrem in Betrem \& Bradley, 1972. Synonymy implied by Osten (2005: 3).

Tribe: Curtaurgini Argaman, 1996: 182. Type genus: Curtaurga Argaman, 1996. $=$ Campsomerini Betrem in Betrem \& Bradley, 1972. Synonymy implied by Osten (2005: 3).

Tribe: Dasyscoliini Argaman, 1996: 181. Type genus: Dasyscolia Bradley, 1951. $=$ Campsomerini Betrem in Betrem \& Bradley, 1972. Synonymy implied by Osten (2005: 3).

Tribe: Dielidini Argaman, 1996: 212. Type genus: Dielis Saussure \& Sichel, 1864. $=$ Campsomerini Betrem in Betrem \& Bradley, 1972. Synonymy implied by Osten (2005: 3).

Tribe: Discoliini Argaman, 1996: 197. Type genus: Discolia Saussure, 1863. =Scoliini Latreille, 1802. Synonymy implied by Osten (2005: 26).

Tribe: Dobrobetini Argaman, 1996: 205. Type genus: Dobrobeta Argaman, 1996. $=$ Campsomerini Betrem in Betrem \& Bradley, 1972. Synonymy implied by Osten (2005: 22).

Tribe: Hangasornini Argaman, 1996: 197. Type genus: Hangasorna Argaman, 1996. =Scoliini Latreille, 1802. Synonymy implied by Osten (2005: 41).

Tribe: Heterelini Argaman, 1996: 183. Type genus: Heterelis Costa, 1887. $=$ Campsomerini Betrem in Betrem \& Bradley, 1972. Synonymy implied by Osten (2005: 3).

Tribe: Lisocini Argaman, 1996: 199. Type genus: Lisoca Costa, 1858. =Scoliini Latreille, 1802. Synonymy implied by Osten (2005: 26).

Tribe: Megacampsomerini Argaman, 1996: 211. Type genus: Megacampsomeris Betrem, 1928. =Campsomerini Betrem in Betrem \& Bradley, 1972. Synonymy implied by Osten (2005: 3).

Tribe: Megascoliini Argaman, 1996: 199. Type genus: Megascolia Betrem, 1928. =Scoliini Latreille, 1802. Synonymy implied by Osten (2005: 26).

Tribe: Pseudotrielidini Argaman, 1996: 205. Type genus: Pseudotrielis Betrem, 1928. =Campsomerini Betrem in Betrem \& Bradley, 1972. Synonymy implied by Osten (2005: 3). 
Tribe: Tetrascitonini Argaman, 1996: 201. Type genus: Tetrasciton Betrem, 1927. $=$ Campsomerini Betrem in Betrem \& Bradley, 1972. Synonymy implied by Osten (2005: 8).

Tribe: Trisciloini Argaman, 1996: 201. Type genus: Trisciloa Gribodo, 1893. =Campsomerini Betrem in Betrem \& Bradley, 1972. Synonymy implied by Osten (2005: 3).

Tribe: Triscoliini Argaman, 1996: 193. Type genus: Triscolia Saussure, 1863. =Scoliini Latreille, 1802. Synonymy implied by Osten (2005: 26).

Tribe: Ycasbraini Argaman, 1996: 191. Type genus: Ycasbraia Argaman, 1996. =Scoliini Latreille, 1802. Synonymy implied by Osten (2005: 42).

Genus: Agombarda Argaman, 1996: 194. Type species: Scolia atra Illiger, 1802. =Discolia Saussure, 1863. Synonymy implied by Osten (2005: 27).

Genus: Ascolia Argaman, 1996: 188. Type species: Scolia flavifrons Fabricius, 1775. Intended as an emendation of Ascoli Guérin-Méneville, 1838 but that name is not available since it was proposed for a hypothetical taxon (GuérinMéneville 1838) and Ascolia must thus be regarded as a new genus. =Regiscolia Betrem \& Bradley, 1964. Synonymy implied by Osten (2005: 37). (The name Ascoli has had a checkered history, being cited in synonymy of Triscolia Saussure, 1863 by Saussure \& Sichel (1864) but being used as valid by Betrem (1926) and thereby technically being made available (ICZN 1999, Article 11.6.1). It has not been used as valid since, and a type species has never been designated. Jacot-Guillarmod et al. (1963) requested the International Commission on Zoological Nomenclature to suppress Ascoli as used by GuérinMénéville (1838) and Betrem (1926), but an Opinion on this has never been issued, which means that prevailing usage (which regards it as unavailable) should be maintained (ICZN 1999, Article 82.1).)

Genus: Bagonasuna Argaman, 1996: 186. Type species: Trielis tartara Morawitz, 1897. =Crioscolia Bradley, 1951. Synonymy implied by Osten (2005: 23); Morawitz ("1897") dealt with Trielis tartara (Saussure, 1880) var. mongolica Morawitz, 1889, however (Morawitz's paper was actually published in 1896, see Oshanin (1910)).

Genus: Batalanga Argaman, 1996: 205. Type species: Elis phalerata Saussure, 1858. Proposed as a new replacement name for Phalerimeris Betrem, 1967 not Betrem, 1966. $=$ Phalerimeris Betrem, 1967. Batalanga is an objective synonym of Phalerimeris Betrem, 1967 because "Phalerimeris Betrem, 1966" is not an available name, merely appearing without any description and stated to be a nomen nudum (Bradley \& Betrem 1966: 74), and therefore cannot be a senior homonym of Phalerimeris Betrem, 1967. (For "Phalerimeris Betrem, 1966" Argaman (1996: 205) used "Phaleromeris Bradley, 1964" but that too is not an available name, having no description (Bradley 1964: 193); Annulimeris Betrem, 1967 should be used for that taxon.)

Genus: Borongorba Argaman, 1996: 213. Type species: Scolia habrocoma Smith, 1855. = Megacampsomeris Betrem, 1928. Synonymy implied by Osten (2005: 12). 
Genus: Burgamurga Argaman, 1996: 194. Type species: Scolia cyanipennis Fabricius, 1804. =Discolia Saussure, 1863. Synonymy implied by Osten (2005: 30).

Genus: Buzatlana Argaman, 1996: 200. Type species: Scolia fuciformis Scopoli, 1786. =Scolia Fabricius, 1775. Synonymy implied by Osten (2005: 33).

Genus: Citberaysa Argaman, 1996: 192. Type species: Scolia ebenina Saussure, 1858. =Austroscolia Betrem, 1928. Synonymy implied by Osten (2005: 31).

Genus: Curtaurga Argaman, 1996: 183. Type species: Scolia aliena Klug, 1832. Proposed as a new replacement name for Guigliana Betrem, 1967 not Bradley, 1964. = Guigliana Betrem, 1967. Curtaurga is an objective synonym of Guigliana Betrem because "Guigliana Bradley, 1964" is not an available name, merely appearing as "Scolia (Guigliana) azurea azurea Christ" without any description (Bradley 1964: 192), and therefore cannot be a senior homonym of Guigliana Betrem. (Osten (2005: 27) placed S. azurea Christ in Megascolia (Regiscolia); there is thus no need for another name for Argaman's concept of "Guigliana Bradley, 1964”.)

Genus: Dobrobeta Argaman, 1996: 206. Type species: Campsomeris socotrana Kirby, 1900. = Cathimeris Betrem, 1972. Synonymy implied by Osten (2005: 22). Genus: Elpaholta Argaman, 1996: 194. Type species: Scolia fulvifrons Saussure, 1854. =Regiscolia Betrem \& Bradley, 1964. Synonymy implied by Osten (2005: 33).

Genus: Fiharbuxa Argaman, 1996: 212. Type species: Scolia prismatica Smith, 1855. = Megacampsomeris Betrem, 1928. Synonymy implied by Osten (2005: 19). Genus: Gondiconda Argaman, 1996: 210. Type species: Elis vittata Sichel, 1864. =Pygodasis Bradley, 1957. Synonymy implied by Osten (2005: 25).

Genus: Hangasorna Argaman, 1996: 197. Type species: Scolia quadripustulata Fabricius, 1782. = Discolia Saussure, 1863. Synonymy implied by Osten (2005: 41).

Genus: Haralambia Argaman, 1996: 215. Type species: Tiphia dorsata Fabricius, $1787 .=$ Dielis Saussure $\&$ Sichel, 1864. Synonymy implied by Osten (2005: 10).

Genus: Hayderiba Argaman, 1996: 209. Type species: Colpa peregrina Lepeletier, 1845. New replacement name for Colpa Lepeletier, 1845 not Dufour, 1841. = Campsomeris Guérin-Ménéville, 1838. Synonymy implied by Osten (2005: 19).

Genus: Hitfoidra Argaman, 1996: 192. Type species: Scolia carnifex Coquerel, 1855. =Austroscolia Betrem, 1928. Synonymy implied by Osten (2005: 29).

Genus: Iforborha Argaman, 1996: 203. Type species: Tiphia collaris Fabricius, 1775. = Campsomeriella Betrem, 1941. Synonymy implied by Osten (2005: 8).

Genus: Iksalonca Argaman, 1996: 199. Type species: Scolia jurinei Saussure, 1854. = Discolia Saussure, 1863. Synonymy implied by Osten (2005: 36).

Genus: Ilkamilka Argaman, 1996: 212. Type species: Campsomeris luzonensis Rohwer, 1921. =Megacampsomeris Betrem, 1928. Synonymy implied by Osten (2005: 16). 
Genus: Jupadora Argaman, 1996: 193. Type species: Scolia cerberia Bradley, 1959. =Microscolia Betrem, 1927. Synonymy implied by Osten (2005: 29); the specific name is also spelled "cereberia" in Bradley (1959), the spelling used by Osten.

Genus: Katapolda Argaman, 1996: 198. Type species: Scolia desidiosa Bingham, 1896. =Discolia Saussure, 1863. Synonymy implied by Osten (2005: 30).

Genus: Kokarevta Argaman, 1996: 200. Type species: Scolia histrionica Fabricius, 1787. = Discolia Saussure, 1863. Synonymy implied by Osten (2005: 35).

Genus: Kukkiya Argaman, 1996: 187. Type species: Scolia moricei Saunders, 1901. = Crioscolia Bradley, 1951. Synonymy implied by Osten (2005: 17).

Genus: Lacosia Argaman, 1996: 199. Type species: Scolia pygmaea Saussure, 1858. Proposed as an emendation of Lacosi Guérin-Méneville, 1838, but must be considered as a new genus different in concept, since Bequaert (1926) had correctly designated the type species of Lacosi as Scolia quadripunctata Fabricius, 1775 , and $S$. pygmaea was not an originally included species of Lacosi Guérin-Méneville. =Discolia Saussure, 1863. Synonymy implied by Osten (2005: 35).

Genus: Laskariska Argaman, 1996: 188. Type species: Scolia haemorrhoidalis Fabricius, 1787. =Regiscolia Betrem \& Bradley, 1964. Synonymy implied by Osten (2005: 37).

Genus: Lobhargita Argaman, 1996: 208. Type species: Scolia aureola Klug, 1832. = Micromeriella Betrem, 1972. Synonymy implied by Osten (2005: 5).

Genus: Molzinarda Argaman, 1996: 192. Type species: Scolia nitida Smith, 1858. =Austroscolia Betrem, 1928. Synonymy implied by Osten (2005: 39).

Genus: Mookitena Argaman, 1996: 215. Type species: Campsomeris hesterae Rohwer, 1927. =Xanthocampsomeris Bradley, 1957. Synonymy implied by Osten (2005: 12).

Genus: Murahutka Argaman, 1996: 190. Type species: Scolia quadriceps Smith, 1859. = Diliacos Saussure \& Sichel, 1864. Synonymy implied by Osten (2005: 41). Genus: Naysebwa Argaman, 1996: 200. Type species: Scolia fulvofimbriata Burmeister, 1853. =Discolia Saussure, 1863. Synonymy implied by Osten (2005: 33). Genus: Niyaranta Argaman, 1996: 213. Type species: Scolia aurulenta Smith, 1855. = Phalerimeris Betrem, 1967 (not Bradley, 1974). Synonymy implied by Osten (2005: 6).

Genus: Nokbibula Argaman, 1996: 191. Type species: Scolia vittifrons Sichel, 1864. = Carinoscolia Betrem, 1927. Synonymy implied by Osten (2005: 45).

Genus: Noybarilta Argaman, 1996: 211. Type species: Scolia hoffmannseggii [sic] Klug, 1805. =Lissocampsomeris Bradley, 1957. Synonymy implied by Osten (2005: 13).

Genus: Onkoknoa Argaman, 1996: 195. Type species: Scolia bilunulata Saussure, 1858. =Discolia Saussure, 1863. Synonymy implied by Osten (2005: 28).

Genus: Ordatirga Argaman, 1996: 185. Type species: Dielis mima Buysson, 1897. =Heterelis Costa, 1887. Synonymy implied by Osten (2005: 17). 
Genus: Orlovinga Argaman, 1996: 199. Type species: Scolia gussakovskii Steinberg, 1953. = Scolia Fabricius, 1775. Synonymy implied by Osten (2005: 34). Genus: Oscalosca Argaman, 1996: 214. Type species: Elis pilipes Saussure, 1858. =Dielis Saussure \& Sichel, 1864. Synonymy implied by Osten (2005: 19).

Genus: Paconzitva Argaman, 1996: 196. Type species: Scolia alecto Smith, 1858. =Regiscolia Betrem \& Bradley, 1964. Synonymy implied by Osten (2005: 26).

Genus: Pardesiya Argaman, 1996: 200. Type species: Scolia neglecta Cyrillo, 1787. =Scolia Fabricius, 1775. Synonymy implied by Osten (2005: 29).

Genus: Pupunhuga Argaman, 1996: 203. Type species: Campsomeris sauteri Betrem, 1928. =Scolia Fabricius, 1775. Synonymy implied by Osten (2005: 42).

Genus: Rahosmula Argaman, 1996: 190. Type species: Scolia sicheli Saussure, 1859. = Discolia Saussure, 1863. Synonymy implied by Osten (2005: 43).

Genus: Rihamlika Argaman, 1996: 195. Type species: Scolia venusta Smith, 1855. = Discolia Saussure, 1863. Synonymy implied by Osten (2005: 45).

Genus: Rostopasca Argaman, 1996: 187. Type species: Scolia erivanensis Radoszkowski, 1879. =Scolia Fabricius, 1775 (?). Possible synonymy implied by Osten (2005: 31).

Genus: Rucarcana Argaman, 1996: 206. Type species: Campsomeris congener Turner, 1909. = Pseudotrielis Betrem, 1928. Synonymy implied by Osten (2005: 9).

Genus: Sisakrosa Argaman, 1996: 204. Type species: Dielis angulata Morawitz, 1888. = Micromeriella Betrem, 1972. Synonymy implied by Osten (2005: 13).

Genus: Sobolpiha Argaman, 1996: 190. Type species: Scolia ribbei Betrem, 1928. =Diliacos Saussure \& Sichel, 1864. Synonymy implied by Osten (2005: 41).

Genus: Stiboranna Argaman, 1996: 198. Type species: Scolia hova Saussure, 1891. = Discolia Saussure, 1863. Synonymy implied by Osten (2005: 35).

Genus: Sugorpilfa Argaman, 1996: 196. Type species: Scolia philippinensis Rohwer, 1921. =Regiscolia Betrem \& Bradley, 1964. Synonymy implied by Osten (2005: 40).

Genus: Susaynata Argaman, 1996: 212. Type species: Camposmeris cochinensis Betrem, 1928. =Megacampsomeris Betrem, 1928. Synonymy implied by Osten (2005: 8).

Genus: Tatusdayca Argaman, 1996: 208. Type species: Scolia ephippium Say, 1837. =Pygodasis Bradley, 1957. Synonymy implied by Osten (2005: 10).

Genus: Titbisayda Argaman, 1996: 213. Type species: Campsomeris binghami Betrem, 1928. = Megacampsomeris Betrem, 1928. Synonymy implied by Osten (2005: 6).

Genus: Tonsoygata Argaman, 1996: 192. Type species: Scolia verticalis Fabricius, 1775. = Discolia Saussure, 1863. Synonymy implied by Osten (2005: 45).

Genus: Torbesula Argaman, 1996: 211. Type species: Elis columba Saussure, 1858. =Lissocampsomeris Bradley, 1957. Synonymy implied by Osten (2005: 8).

Genus: Turturayca Argaman, 1996: 190. Type species: Scolia fulgidipennis Smith, 1859. =Liacos Guérin-Ménéville, 1838. Synonymy implied by Osten (2005: 33). 
Genus: Ululanca Argaman, 1996: 189. Type species: Scolia nigrita Fabricius, 1782. =Liacos Guérin-Ménéville, 1838. Synonymy implied by Osten (2005: 38).

Genus: Uthakkara Argaman, 1996: 202. Type species: Campsomeris celebensis Betrem, 1928. = Megacampsomeris Betrem, 1928. Synonymy implied by Osten (2005: 8).

Genus: Vardombra Argaman, 1996: 198. Type species: Scolia picteti Saussure, 1854. =Discolia Saussure, 1863. Synonymy implied by Osten (2005: 40).

Genus: Vobalayca Argaman, 1996: 201. Type species: Scolia hortorum Fabricius, 1787. = Scolia Fabricius, 1775. Synonymy implied by Osten (2005: 35).

Genus: Wogungela Argaman, 1996: 198. Type species: Scolia micromelas Sichel, 1864. =Discolia Saussure, 1863. Synonymy implied by Osten (2005: 38).

Genus: Xirgoniqua Argaman, 1996: 196. Type species: Scolia capitata Fabricius, 1804. = Regiscolia Betrem \& Bradley, 1964. Synonymy implied by Osten (2005: 29).

Genus: Ycasbraia Argaman, 1996: 193. Type species: Scolia rufiventris Fabricius, 1804. = Hesperoscolia Bradley, 1974. Synonymy implied by Osten (2005: 42); actually an objective synonym.

Genus: Yohaida Argaman, 1996: 186. Type species: Scolia klugi van der Linden, 1829. = Colpa Dufour, 1841. Synonymy implied by Osten (2005: 14).

Genus: Zazilayza Argaman, 1996: 188. Type species: Scolia rubida Gribodo, 1893. =Regiscolia Betrem \& Bradley, 1964. Synonymy implied by Osten (2005: 42).

Species:

[Discolia kugleri Nagy, 1979. This is an unavailable manuscript name and date on several specimens in the Tel Aviv Collection, which evidently has never been published; it was given as a synonym of Scolia fallax Eversmann, 1849 by Osten (2002: 347).]

[Megascolia flavifrons f. vernalis Nagy, 1967d: 223. "Holotype" female; Romania: Nicolina near Iaşi (Nagy Coll.). Name not available (Article 15.2, ICZN 1999).]

[Megascolia flavifrons f. vespertina Nagy, 1967d: 223. "Holotype" female; Romania: Agigea (Nagy Coll.). Name not available (Article 15.2, ICZN 1999).] Scolia (Scolia) incana Nagy, 1970k: 322. Holotype female; Mongolia: Bajanchongor aimak, Echin gol, cca $90 \mathrm{~km} \mathrm{NO}$ von Grenzposten Caganbulag (Budapest, confirmed). =Scolia (Scolia) concolor Eversmann, 1849. Synonymized by Osten (1997: 517).

Scolia (Discolia) mongolina Nagy, 1970k: 323. Holotype female; Mongolia: Bulgan aimak, $4 \mathrm{~km} \mathrm{~S}$ von Somon Daschiněilen (Budapest, confirmed). $=$ Scolia hirta Schrank, 1781. Synonymized by Osten (1997: 515).

Scolioides alutus Nagy, 1967d: 224. Holotype male; Romania: Murta, Oltenia (Nagy Coll.). =Scolia hirta Schrank, 1781. Synonymized by Hamon (1993: 95). 


\section{Family Sierolomorphidae}

Species:

Sierolomorpha isis Nagy, 1971b: 247. Holotype female; Samarkand (Nagy Coll.).

Sierolomorpha atropos Nagy, 1971b: 248. Holotype female; N. China: Kerulen (Nagy Coll.).

Family Tiphiidae [many treated under Family Myzinidae by Nagy/Argaman, but generally considered as subfamily Myzininae Ashmead, 1899]

Subfamily: Iswarinae Argaman, 1994b: 89. Type genus: Iswara Westwood, 1850. =Meriina Argaman, 1994. Synonymized by Boni Bartalucci (2004a: 1245).

Subfamily: Meriinae Argaman, 1994b: 91. Type genus: Meria Illiger, 1807. Considered as tribe Meriini Argaman, 1994 by Boni Bartalucci (2004a: 1218).

Subfamily: Mesinae Argaman, 1994b: 90. Type genus: Mesa Saussure, 1892. Considered as tribe Mesini Argaman, 1994 by Boni Bartalucci (2004a: 1218).

Subfamily: Silifkinae Argaman \& Özbek, 1992: 5. Type genus: Silifka Argaman \& Özbek, 1992. Considered as tribe Silifkini Argaman \& Özbek, 1992 by Yildirim $\&$ Boni Bartalucci (2009: 2054).

Tribe: Acblasini Argaman \& Özbek, 1992: 10. Type genus: Acblasa Argaman in Argaman \& Özbek, 1992. =Tiphiini Leach, 1815. Synonymy implied by Yildirim \& Boni Bartalucci (2009) in not recognizing higher taxa within Tiphiini.

Tribe: Burdufini Argaman \& Özbek, 1992: 11. Type genus: Burdufa Argaman in Argaman \& Özbek, 1992. =Tiphiini Leach, 1815. Synonymy implied by Yildirim \& Boni Bartalucci (2009) in not recognizing higher taxa within Tiphiini.

Tribe: Cabaraxini Argaman \& Özbek, 1992: 10. Type genus Cabaraxa Nagy, 1974. $=$ Tiphiini Leach, 1815 . Synonymy implied by Yildirim \& Boni Bartalucci (2009) in not recognizing higher taxa within Tiphiini.

Tribe: Epomidiopterini Argaman \& Özbek, 1992: 8. Type genus Epomidiopteron Romand, 1835. =Silifkini Argaman \& Özbek, 1992. Synonymy implied by Yildirim \& Boni Bartalucci (2009) in not recognizing higher taxa within Siflikini.

Tribe: Hylomesini Agaman, 1994b: 90. Type genus: Hylomesa Krombein, 1968. $=$ Mesini Argaman, 1994b. Synonymy implied by Boni Bartalucci (2004a) in not recognizing higher taxa within Mesini.

Tribe: Icronathini Argaman \& Özbek, 1992: 11. Type genus: Icronatha Nagy, 1967. = Tiphiini Leach, 1815. Synonymy implied by Yildirim \& Boni Bartalucci (2009) in not recognizing higher taxa within Tiphiini.

Tribe: Illoswiini Argaman, 1994b: 92. Type genus: Illoswia Argaman, 1994. =Meriina Argaman, 1994b. Synonymy implied by Boni Bartalucci (2004a) in recognizing only two tribes within Meriini.

Tribe: Iswarini Argaman, 1994b: 89. Type genus: Iswara Westwood, 1850. =Meriina Argaman, 1994b. Synonymy implied by Boni Bartalucci (2004a) in recognizing only two tribes within Meriini. 
Tribe: Jaynesiini Argaman \& Özbek, 1992: 10. Type genus: Jaynesia Allen, 1969. $=$ Tiphiini Leach, 1815. Synonymy implied by Yildirim \& Boni Bartalucci (2009) in not recognizing higher taxa within Tiphiini.

Tribe: Komarowiini Argaman, 1994b: 92. Type genus: Komarowia Radoszkowski, 1886. =Meriina Argaman, 1994b. Synonymy implied by Boni Bartalucci (2004a) in recognizing only two tribes within Meriini.

Tribe: Krombeiniini Argaman \& Özbek, 1992: 10. Type genus: Krombeinia Pate, 1947. = Tiphiini Leach, 1815. Synonymy implied by Yildirim \& Boni Bartalucci (2009) in not recognizing higher taxa within Tiphiini.

Tribe: Luditini Argaman \& Özbek, 1992: 10. Type genus Ludita Nagy, 1967. $=$ Tiphiini Leach, 1815. Synonymy implied by Yildirim \& Boni Bartalucci (2009) in not recognizing higher taxa within Tiphiini.

Tribe: Macromeriini Argaman, 1994b: 94. Type genus: Macromeria Saunders, 1850. =Meriina Argaman, 1994b. Synonymy implied by Boni Bartalucci (2004a) in recognizing only two tribes within Meriini.

Tribe: Meriini Argaman, 1994b: 95. Type genus: Meria Illiger, 1807.

Tribe: Mesini Argaman, 1994b: 90. Type genus: Mesa Saussure, 1892.

Tribe: Myzinellini Argaman, 1994b: 89. Type genus: Myzinella Guiglia, 1959. =Meriina Argaman, 1994b. Synonymy implied by Boni Bartalucci (2004a) in recognizing only two tribes within Meriini.

Tribe: Neotiphiini Argaman \& Özbek, 1992: 9. Type genus: Neotiphia Malloch, 1918. = Tiphiini Leach, 1815. Synonymy implied by Yildirim \& Boni Bartalucci (2009) in not recognizing higher taxa within Tiphiini.

Tribe: Parameriini Argaman, 1994b: 92. Type genus: Parameria Guérin-Méneville, 1837. =Meriina Argaman, 1994b. Synonymy implied by Boni Bartalucci (2004a) in recognizing only two tribes within Meriini.

Tribe: Paratiphiini Argaman \& Özbek, 1992: 9. Type genus: Paratiphia Sichel, 1864. =Silifkini Argaman \& Özbek, 1992. Synonymy implied by Yildirim \& Boni Bartalucci (2009) in not recognizing higher taxa within Siflikini.

Tribe: Poecilotiphiini Argaman, 1994b: 93. Type genus: Poecilotiphia Cameron, 1902. =Meriina Argaman, 1994b. Synonymy implied by Boni Bartalucci (2004a) in recognizing only two tribes within Meriini.

Tribe: Pseudotiphiini Argaman \& Özbek, 1992: 9. Type genus: Pseudotiphia Ashmead, 1903. = Tiphiini Leach, 1815. Synonymy implied by Yildirim \& Boni Bartalucci (2009) in not recognizing higher taxa within Tiphiini.

Tribe: Silifkini Argaman \& Özbek, 1992: 9. Type genus: Silifka Argaman \& Özbek, 1992.

Tribe: Warayoini Argaman, 1994b: 91. Type genus: Warayoa Argaman, 1994. =Meriina Argaman, 1994b. Synonymy implied by Boni Bartalucci (2004a) in recognizing only two tribes within Meriini.

Tribe: Weerpagini Argaman, 1994b: 92. Type genus: Weerpaga Argaman, 1994. $=$ Braunsomeriina Boni Bartalucci, 2004. Synonymy implied by Boni Bartalucci (2004a) in recognizing only two tribes within Meriini. 
Tribe: Yooloini Argaman, 1994b: 92. Type genus: Yooloa Argaman, 1994. = Meriina Argaman, 1994b. Synonymy implied by Boni Bartalucci (2004a) in recognizing only two tribes within Meriini.

Genus: Acblasa Argaman in Argaman \& Özbek, 1992: 10. Type species: Tiphia abrupta Turner, 1908.

Genus: Arapatka Argaman, 1994b: 94. Type species: Myzine arabica Guérin-Méneville 1837. = Meria Illiger, 1807. Synonymized by Boni Bartalucci (2001: 3).

Genus: Burdufa Argaman in Argaman \& Özbek, 1992: 11. Type species: Tiphia colombiana Allen, 1972.

Genus: Cabaraxa Nagy, 1974d: 103. Type species: Cabaraxa compedita Nagy, 1974.

Genus: Cocovasna Argaman, 1994b: 86. Myzine flavopicta Smith, 1855. =Myzinum Latreille, 1803. Synonymized by Boni Bartalucci (2004a: 1225).

Genus: Ekepirka Argaman, 1994b: 88. Type species: Myzine robusta Burmeister, 1876. = Myzinum Latreille, 1803. Synonymized by Kimsey 2009.

Genus: Fikoplesa Argaman, 1994b: 88. Type species: Myzine elegans Burmeister, 1876. =Myzinum Latreille, 1803. Synonymized by Kimsey 2009.

Genus: Foforoxia Argaman in Argaman \& Özbek, 1992: 11. Type species: Tiphia ordinaria Smith, 1873.

Genus: Fongiba Argaman, 1994b: 93. Type species: Myzine aegyptiaca GuérinMéneville, 1837. = Poecilotiphia Cameron, 1902. Synonymized by Boni Bartalucci (2001: 28).

Genus: Fukpokta Argaman, 1994b: 95. Type species: Scolia cylindrica Fabricius, 1793. = Meria Illiger, 1807. Synonymized by Boni Bartalucci (2001: 3; misspelled as Fukpotka).

Genus: Gebuipala Argaman in Argaman \& Özbek, 1992: 11. Type species: Icronatha nuristana Nagy, 1975.

Genus: Gonordula Argaman, 1994b: 87. Type species: Myzine lateralis Cresson, 1865. = Myzinum Latreille, 1803. Synonymized by Boni Bartalucci (2004a: 1225).

Genus: Hahiya Argaman, 1994b: 94. Type species: Meria brevicauda Morawitz, 1890. = Poecilotiphia Cameron, 1902. Synonymized by Boni Bartalucci (2001: 28).

Genus: Icronatha Nagy, 1967c: 193. Type species: Tiphia olcesei Tournier, 1889.

Genus: Illoswia Argaman, 1994b: 92. Type species: Myzine braunsi Turner, 1912. = Myzinella Guiglia, 1959. Synonymized by Boni Bartalucci (2001: 23).

Genus: Ivazuga Argaman, 1994b: 94. Type species: Dermasothes trjapitzini Gorbatovsky, 1979. = Poecilotiphia Cameron, 1902. Synonymized by Boni Bartalucci (2001: 28).

Genus: Jurja Argaman, 1994b: 93. Type species: Jurja limpida Argaman, 1994. =Poecilotiphia Cameron, 1902. Synonymized by Boni Bartalucci (2001: 28).

Genus: Keyovaska Argaman, 1994b: 88. Type species: Myzine frontalis Cresson, 1875. = Myzinum Latreille, 1803. Synonymized by Boni Bartalucci (2004a: 1225).

Genus: Locodamia Argaman \& Özbek, 1992: 10. Type species: Tiphia sulcata Roberts, 1930. 
Genus: Ludita Nagy, 1967c: 197. Type species: Tiphia morio Fabricius, 1787. Genus: Nurmiya Argaman, 1994b: 94. Type species: Meria contrastata Guiglia, 1963. =Poecilotiphia Cameron, 1902. Synonymized by Boni Bartalucci (2001: 28).

Genus: Nyuka Argaman, 1994b: 90. Type species: Plesia picticollis Morawitz, 1890. = Mesa Saussure, 1892. Synonymized by Boni Bartalucci (2004a: 1228).

Genus: Ocasasla Argaman in Argaman \& Özbek, 1992: 10. Type species: Tiphia vandervechti Allen, 1972.

Genus: Pandasaria Argaman in Argaman \& Özbek, 1992: 11. Type species: Tiphia latipes Walker, 1871.

Genus: Sasmarila Argaman in Argaman \& Özbek, 1992: 11. Type species: Tiphia cinchonae Allen, 1975.

Genus: Serpapinta Argaman in Argaman \& Özbek, 1992: 9. Type species: Tiphia scabrosa Gerstaecker, 1858.

Genus: Silifka Argaman \& Özbek, 1992: 5. Type species: Silifka fatima Argaman \& Özbek, 1992.

Genus: Taywola Argaman, 1994b: 91. Type species: Mesa palestinella Guiglia, 1963. = Mesa Saussure, 1892. Synonymized by Boni Bartalucci (2004b: 365).

Genus: Tilkuya Argaman, 1994b: 96. Type species: Myzine spinosa Fischer de Waldheim, 1843. =Meria Illiger, 1807. Synonymized by Boni Bartalucci (2001: 3).

Genus: Tokoparta Argaman, 1994b: 88. Type species: Plesia sexmaculata GuérinMéneville, 1838. =Myzinum Latreille, 1803. Synonymized by Kimsey 2009.

Genus: Upaterka Argaman, 1994b: 95. Type species: Myzine latifasciata Palma, 1869. = Meria Illiger, 1807. Synonymized by Boni Bartalucci (2001:3).

Genus: Vacacunda Argaman in Argaman \& Özbek, 1992: 10. Type species: Tiphia quincemila Allen, 1972.

Genus: Warayoa Nagy, 1994b: 91. Type species: Warayoa citreosigna Argaman, 1994. =Braunsomeria Turner, 1912. Synonymized by Boni Bartalucci (2011:371).

Genus: Weerpaga Argaman, 1994b: 92. Type species: Weerpaga udomanca Argaman, 1994.

Genus: Xilunka Nagy, 1994b: 90. Type species: Cosila donaldsoni Fox, 1896. $=$ Mesa Saussure, 1892. Synonymized by Boni Bartalucci (2004b: 365).

Genus: Yooloa Argaman, 1994b: 92. Type species: Yooloa vircola Argaman, 1994. = Parameria Guérin-Méneville, 1837. Synonymized by Boni Bartalucci (2001: 27).

Genus: Zezelda Nagy, 1994b: 90. Type species: Myzine stigma Turner, 1912.

Subgenus: Sierocolpa Nagy, 1967c: 177. Type species: Tiphia minuta van der Linden, 1827

Species:

Cabaraxa compedita Nagy, 1974d: 104. Holotype male; Ethiopia: Dire-Dana (belongs in Budapest, but not deposited there).

Dermasothes ponderopardalis Nagy, 1970d: 191. Holotype male; South Africa: Cape Prov., Willowmore (Nagy Coll.). 
Icronatha nuristana Nagy, 1975a: 17. Holotype female; Afghanistan: Nuristan (Nagy Coll.).

Jurja limpida Argaman, 1994b: 96. Holotype male; Yemen: Wadi Zabid (belongs in Budapest, but not deposited there).

Ludita andromeda Nagy, 1967c: 198. Holotype female; Romania: Babadag (Nagy Coll.).

Ludita consobrina Nagy, 1967c: 202. Holotype male; Romania: Rarău Gebirge (Nagy Coll.).

Ludita ramispinosa Nagy, 1967c: 203. Holotype male; Romania: Caraorman, Rayon Tulcea (Nagy Coll.).

Methoca [sic] sisala Nagy, 1968e: 82. Holotype male; Romania: near Oradea, Băile Felix forest (Nagy Coll.).

Silifka fatima Argaman \& Özbek, 1992: 6. Holotype female; Turkey: Silifke (Argaman Coll.)

Tiphia (Tiphia) bexar Nagy, 1967c: 187. Holotype female; Romania: Oituz (Nagy Coll.).

Tiphia (Tiphia) copidosoma Nagy, 1967c: 189. Holotype female; Romania: Băile Victoria (Nagy Coll.)

Tiphia (Tiphia) iracunda Nagy, 1967c: 182. Holotype male; Romania: Agigea (Nagy Coll.).

Warayoa citreosigna Argaman, 1994b: 91. Holotype male = paratype of Braunsomeria quadraticeps Turner, 1912; South Africa: "Cape Colony", Willowmore (London) [although Argaman considered this a replacement name, it must rather be treated as the proposal of a new species since he retained Turner's name for the female; although Boni Bartalucci (2011) designated the female specimen as the lectotype, this is invalid since Turner (1912) had specified "the female is the type", effectively designating it as the holotype]. = Braunsomeria quadraticeps Turner, 1912. Synonymized by Boni Bartalucci 2011.

Weerpaga udomanca Argaman, 1994b: 98. Holotype female; Cameroon: Guetale (Nonveiller Coll.).

Yooloa vircola Argaman, 1994b: 97. Holotype male; Israel: Mikhmoret, Miramare Hotel garden (Argaman Coll.). = Parameria femorata Guérin, 1837. Synonymized by Boni Bartalucci (2001: 27).

\section{Order Coleoptera}

\section{Family Scarabaeidae}

Species:

Maladera matrida Argaman, 1986b: 43, 68. Holotype male; Israel: Rehovot $($ Tel Aviv University). = Maladera insanabilis (Brenske, 1894). Synonymized by Ahrens (2000: 202, as Autoserica insanabilis). 